\title{
REVIEW:
}

\section{COPPER IN PLANTS: ACQUISITION, TRANSPORT AND INTERACTIONS}

Inmaculada Yruela

Estación Experimental de Aula Dei, Consejo Superior de Investigaciones Cientificas (CSIC), Avda. Montañana, 1005, 50059 Zaragoza, Spain.

E-mail: yruela@eead.csic.es

\section{ABSTRACT}

Copper is an essential metal for plants. It plays key roles in photosynthetic and respiratory electron transport chains, in ethylene sensing, cell wall metabolism, oxidative stress protection and biogenesis of molybdenum cofactor. Thus, deficiency in the copper supply can alter essential functions in plant metabolism. On the other hand, copper during decades has been used in agriculture as an antifungal agent and it is also extensively released into the environment by human activities that often cause environmental pollution. Accordingly, excess copper is present in certain regions and environments, and exposure to that can be potentially toxic to plants causing phytotoxicity by the formation of reactive oxygen radicals that damage cells or by the interaction with proteins impairing key cellular processes, inactivating enzymes and disturbing protein structure. Plants have a complex network of metal trafficking pathways in order to appropriately regulate copper homeostasis in response to environmental copper level variations. Such strategies must prevent accumulation of the metal in the freely reactive form (metal detoxification pathways) and to ensure proper delivery of this element to target metalloproteins. The mechanisms involved in the acquisition and the distribution of copper have not been clearly defined although emerging data in last decade, mainly obtained on copper uptake, and both intra- and intercellular distribution, as well as on long-distance transport, are contributing to the understanding of copper homeostasis in plants and the response to copper stress. This review gives a brief overview of the current understanding of main features concerning copper function, acquisition and trafficking network as well as interactions between copper and other 
elements.

Keywords: deficiency, regulation, response, trafficking network, tolerance, toxicity

\section{INTRODUCTION}

Plants require mineral nutrient elements, predominantly acquired from the soil but also from foliar applications, to maintain normal growth and development and ensure the completion of life cycles. The acquisition and distribution of these elements are important targets for research because their metabolic and biochemical functions are associated with all aspects of plant physiology, plant biochemistry and plant molecular biology. Copper $(\mathrm{Cu})$ is a redox-active transition metal essential for plants as well as for all living organisms. $\mathrm{Cu}$ participates in many physiological processes because it is able to exit in multiple oxidation states in vivo. Under physiological conditions $\mathrm{Cu}$ exist

as $\mathrm{Cu}^{2+}$ and $\mathrm{Cu}^{+}$. The cation $\mathrm{Cu}^{2+}$ is often bound by nitrogen in histidine side chains, whereas $\mathrm{Cu}$ prefers interaction with the sulphur in cysteine or methionine. $\mathrm{Cu}$ acts as structural element in certain metalloproteins, many of which are involved in electron transport in chloroplasts and mitochondria as well as in oxidative stress response. $\mathrm{Cu}$ ions act as cofactor in enzymes such as $\mathrm{Cu} / \mathrm{Zn}$-superoxide dismutase ( $\mathrm{Cu} / \mathrm{ZnSOD})$, cytochrome c oxidase, ascorbate oxidase, amino oxidase, laccase, plastocyanin and polyphenol oxidase. At cellular level, $\mathrm{Cu}$ plays an essential role in cell wall metabolism, signalling to the transcription and protein trafficking machinery, oxidative phosphorylation, iron mobilization and the biogenesis of molybdenum cofactor (for reviews see Raven et al. 1999; Yruela 2005; Gratão et al. 2005; Pilon et al. 2006; Krämer and Clemens 2006; Puig et al. 2007).

Thus, plants require $\mathrm{Cu}$ for normal growth and development, and when this ion is not available, plants develop specific deficiency symptoms, most of which affect young leaves and reproductive organs. On the other hand, the redox properties that make $\mathrm{Cu}$ essential element also 
contribute to its inherent toxicity. Redox cycling between $\mathrm{Cu}^{2+}$ and $\mathrm{Cu}^{+}$can catalyze the production of highly toxic hydroxyl radicals, with subsequent damage to cells at level of lipids, membranes, nucleic acids, proteins and other biomolecules (Halliwell and Gutteridge 1984). Although Cu usually binds to proteins it has capacity to initiate oxidative damage and interfere with important cellular processes such as photosynthesis, pigment synthesis, plasma membrane permeability and other metabolic mechanisms, causing a strong inhibition of plant development (van Assche and Clijsters 1990; Marschner 1995; Küpper et al. 2003; Bertrand and Poirier 2005; Yruela 2005). Cu in excess can become extremely toxic causing symptoms such as chlorosis and necrosis, stunting, and inhibition of root and shoot growth. At cellular level, excess $\mathrm{Cu}$ can inactivate and disturb protein structure as a result of unavoidable binding to proteins. Toxicity may result from: $i$ ) binding to sulfhydryl groups in proteins, thereby inhibiting enzyme activity or protein function; ii) induction of a deficiency of other essential ions; iii) impaired cell transport processes; $i v$ ) oxidative damage.

Nevertheless, either $\mathrm{Cu}$ deficiency or excess $\mathrm{Cu}$ can cause disorders in plant growth and development by adversely affecting important physiological processes in plants. For healthy plant growth and development $\mathrm{Cu}$ must be acquired from the soil, transported throughout the plant, distributed and compartmentalized within different tissues and its content carefully regulated within different cells and organelles. Tissue and cellular concentrations of $\mathrm{Cu}$ need to be controlled within a narrow physiological range. For this purpose, plants - like all other organisms- have homeostatic mechanisms to acquire appropriate amounts of $\mathrm{Cu}$ in diverse environmental conditions and precisely delivering it to specific compartments and target to metalloproteins while avoiding its toxic effect. Thus, the acquisition and assimilation of $\mathrm{Cu}$ must be coordinated with mineral supply and plant demand in a complex and regulated interacting network. $\mathrm{Cu}$ homeostasis processes are dynamic in nature and respond to metal availability, annual cycles, and growth phases.

Although the mineral nutrition of higher plants is of fundamental importance to agriculture and human health, many basic questions remain unanswered, particularly in relation to the 
accumulation of essential heavy metals. Which mechanisms explain that all tissues receive an adequate supply of the heavy metals required for vital cellular processes? Which mechanisms prevent plants from accumulating to toxic levels? These are some questions of fundamental importance in plant biology, which underlie an emerging area of research now that the complete sequencing of several genomes and the necessary molecular tools are available. Genomic approaches are being applied to understand the processes of nutrient acquisition, assimilation and metabolism. In particular, the studies developed in the yeast Saccharomyces cerevisiae have contributed to progress in the knowledge of basic cellular components of $\mathrm{Cu}$ homeostasis in eukaryotic organisms. The use of genetic and molecular techniques such as sequence comparison to identify transporters, functional complementation of yeast mutants and plant transformation to regulate gene activities has been crucial for this development. A wide range of gene families and proteins are being identified in plants that are likely to be involved in $\mathrm{Cu}$ homeostasis. $\mathrm{Cu}$ homeostasis is also receiving a growing interest in plant research since it is implicated in adaptive responses to the oxidative damage produced by environmental stress. Mechanisms must exist to satisfy the requirements of cellular metabolism and at the same time to protect cells from toxic effects. At cellular level, specific transporters are responsible for the uptake and secretion of metal ions, and there may be additional transporters that allow sequestration into organelles. In particular, the interaction of metal chaperones with transporters deserves attention since this may have important implications for sequestration of metals within intracellular stores. During the last ten years a rapid progress has been made in this area. Thus, heavy metal homeostasis is a very exciting and fast developing field in plant biology.

This review gives a briefly overview of the current understanding of main features concerning to $\mathrm{Cu}$ acquisition, trafficking network and interactions between $\mathrm{Cu}$ and other metal ions as well as $\mathrm{Cu}$ regulatory and tolerance mechanisms. 


\section{COPPER FUNCTIONS, ACQUISITION AND TRANSPORT}

\subsection{Copper bioavailability.}

$\mathrm{Cu}$ concentration in vegetative plant tissues varies depending on plant species or ecotypes, developmental stage and environmental factors such as nitrogen supply and soil chemical properties. For instance: i) plants grown under high nitrogen supply require significantly more $\mathrm{Cu}$; ii) $\mathrm{Cu}$ bioavailability tends to be larger in acidic soils. It has been reported that the $\mathrm{Cu}$ concentration in plant tissues is between 1 and $5 \mu g^{-1}$ dry weight (Marschner 1995) and the average composition of $\mathrm{Cu}$ in leaves is $10 \mu \mathrm{gg}^{-1}$ dry weight $\left(5-20 \mu \mathrm{g} \mathrm{g}^{-1}\right.$ dry weight) (Baker and Senef 1995) but these concentrations can vary among plant species and varieties. Cu concentrations in cells need to be maintained at low levels since this element is extremely toxic in view of its high redox properties. The critical free $\mathrm{Cu}$ concentration in the nutrient media (below which $\mathrm{Cu}$ deficiency occurs) ranges from $10^{-14}$ to $10^{-16} \mathrm{M}$. Plants usually find a variable supply of $\mathrm{Cu}$ in the soil since typically soil solution concentrations range from $10^{-6}$ to $10^{-9} \mathrm{M}$ (Marschner 1995), but plants may still need to solubilize and reduce the metal.

Concentrations of free metal ions or metal chelates in the soil solution are generally rather low although this depends on soil properties (Kochian 1991; Marschner 1995). In both soil solution and solid phase $\mathrm{Cu}$ is mainly associated with inorganic and organic matter by complexation or absorption. $\mathrm{Cu}$ ions have a high affinity for binding sites of soil components, as well as can be absorbed onto surfaces of clays and Fe or Mn oxides, co-precipitated with carbonates and phosphates or present in the lattice of primary silicate minerals. $\mathrm{Cu}$ ions can be also bound to cell walls and to the outer membrane surface of plant root cells. The distribution of $\mathrm{Cu}$ among these various solid and plant components will greatly influence the chemical mobility and hence the amount of $\mathrm{Cu}$ potentially taken up by plants. At acidic $\mathrm{pH}$, dissolved $\mathrm{Cu}$ will increase because of its weaker adsorption and so will increase the free $\mathrm{Cu}$ ion activity. Additionally, with increasing $\mathrm{pH}$, 
competitive adsorption will arise between organic matters in the solid phase and dissolved organic carbon, generally leading to an increase in $\mathrm{Cu}$ concentration in the soil solution due to an increase of dissolved organic carbon (Carrillo-González et al. 2006). Thus, upon increasing $\mathrm{pH}$, the $\mathrm{Cu}$ ions activity considerably will decrease at the expense of organically bound complexes species in the soil solution (Sauvé et al. 1997).

On the other hand, in the rizhosphere, root and microbial activities can influence the chemical mobility of metal ions and ultimately their uptake by plants as consequence of alterations of soil $\mathrm{pH}$ or dissolved organic carbon (Hinsinger and Courchesne 2007). For instance, in the case of Graminaceous species, the increased root secretion of Fe-chelating compounds (phytosiderophores) under Fe deficiency has been reported to increase $\mathrm{Cu}$ uptake in a calcareous soil (Chaignon et al. 2002). It is noticeable that soil chemical properties can differ between the bulk soil and the rizhosphere, so considering only properties in the bulk soil might be a poor predictor of $\mathrm{Cu}$ bioavailability and ultimately $\mathrm{Cu}$ uptake which rather depends on the particular properties induced by roots in the rizhosphere. Accordingly, contradictory results concerning the effect of $\mathrm{pH}$ on $\mathrm{Cu}$ uptake by plants are found in the literature. In very acidic soils, plant $\mathrm{Cu}$ concentration increased compared to calcareous soils in rape (Brassica napus L.) and tomato (Lycopersicon esculentum L.) (Chaignon et al. 2003; Cornu et al. 2007). On the contrary, Cu accumulation in maize (Zea mays L.) was as high in calcareous soils as in acidic soils (Brun et al. 2001). Michaud et al. (2007) did not found a clear relationship between $\mathrm{Cu}$ uptake and soil $\mathrm{pH}$ in durum wheat (Triticum turgidum durum L.) in $\mathrm{Cu}$-contaminated soils, probably due to the implication of root-induced changes of $\mathrm{pH}$ and dissolved organic carbon in the rizhosphere. At low $\mathrm{pH}$, alkalization in the rizhosphere was observed compared with the bulk soil, which may result in a reduced $\mathrm{Cu}$ bioavailability. In calcareous soils, a larger chemical mobility may be related to phytosiderophore secretion leading to greater $\mathrm{Cu}$ uptake in plants. 


\subsection{Copper function in plants}

Within the plant cell, $\mathrm{Cu}$ is required in at least six locations: the cytosol, the endoplasmic reticulum (ER), the mitochondrial inner membrane, the chloroplast stroma, the thylakoid lumen and the apoplast (Marschner 1995). The number of $\mathrm{Cu}$-dependent proteins in plants is generally smaller compared with other metal-dependent proteins (metalloproteins). In Arabidopsis proteome can be found 105 and 21 proteins searching "copper protein" and "copper-binding protein" terms, respectively (Krämer and Clemens 2006). The most abundant $\mathrm{Cu}$ proteins in green tissues are plastocyanin and $\mathrm{Cu} / \mathrm{ZnSOD}$. In Arabidopsis $\mathrm{Cu} / \mathrm{ZnSOD}$ is present in three isoforms, of which the major isoforms are found in the cytosol (CSD1) and chloroplast stroma (CSD2), and the third isoform is found in peroxisome (CSD3) (Kanematsu and Asada 1989; Bueno et al. 1995). In maize four cytosol $\mathrm{Cu} / \mathrm{ZnSOD}$ isoenzymes have been found (Kernodle and Scandalios 2001).

In addition to plastocyanin and $\mathrm{Cu} / \mathrm{ZnSOD}$ there is a large number $(>32)$ of related proteins (blue-copper binding proteins) with unknown functions encoded in the Arabidopsis genome (Nerissian et al. 1998). For instance, the existence of a $\mathrm{Cu}$ protein involved in photosynthetic reactions of photosystem II (PSII) non-dependent of plastocyanin was reported earlier (Lightbody and Krognann 1967; Barr and Crane 1976). More recently, Burda et al. (2002) found that Cu in an equimolar concentration to PSII reaction centre stimulated in vitro the oxygen-evolution activity of PSII. Nevertheless, little information respect to this event exists in vivo. An important characteristic of $\mathrm{Cu}^{+}$is its ability to bind small molecules such as $\mathrm{O}_{2}$ as ligands. Thus, $\mathrm{Cu}$ is a cofactor of a large number of oxidases. The best-known oxidase is the mitochondrial cytochrome c oxidase. Other members of this enzyme group are: $i$ ) amine oxidase enzymes associated to the cell wall that catalyzes the oxidation of putrescine that produces $\mathrm{H}_{2} \mathrm{O}_{2}$ involved in lignification, cross-linking of cell wall proteins and programmed cell death (Moller and McPherson 1998); ii) multi-copper oxidases such as ascorbate oxidases that localize in the apoplast and regulate its redox state, and 
laccases also localized in the apoplast but not functionally well understood although a role in lignification has been proposed (Ramocha et al. 2002); iii) multi-copper oxidase-like proteins such as SKU5, which are involved in cell wall formation (Sedbrook et al. 2002); iv) polyphenol oxidase found in the thylakoids of some plants, such as spinach (Kieselbach et al. 1998) but not in other species such as Arabidopsis (Schubert et al. 2002) that is involved in ROS defence. $\mathrm{Cu}^{+}$can also bind ethylene. Accordingly, the ethylene receptor ETR1, which localizes in the endoplasmic reticulum (ER), is dependent on $\mathrm{Cu}$ (Rodriguez et al. 1999). Recently, the role of $\mathrm{Cu}$ in the synthesis of a molybdenum cofactor has been proposed (Kuper et al. 2004). This observation now links $\mathrm{Cu}$ metabolism to nitrogen assimilation and phytochrome biosynthesis (Mendel 2005).

\subsection{Copper acquisition and transport}

$\mathrm{Cu}$ acquisition and transport into and within cells is relatively little known in plants but in the last ten years rapid progress has been made to understand these processes within plant cells, particularly with the application of the knowledge in yeast to other eukaryotes organisms. Consequently, several families of heavy metal transporters involved in intracellular homeostasis have been identified in plants (for reviews see Fox and Guerinot 1998; Himelblau and Amasino 2000; Williams et al. 2000; Markossian and Kurganov 2003; Krämer and Clemens 2006; Colangelo and Guerinot 2006; Puig et al. 2007). However little results have been obtained respect to long-distance transport or transport processes taking place at root level. For instance, at present it is not clear how plant roots actively mobilize $\mathrm{Cu}$ ions. Phytosiderophore secretion by monocots is known to enhance $\mathrm{Cu}$ mobilization (Römheld 1991) but there is no evidence for the uptake of Cu-phytosiderophore complexes by plant roots. The recent progress made on the $\mathrm{Cu}$ acquisition, transport and distribution is presented here (Fig. 1, Table 1). 


\subsubsection{COPT copper transporters}

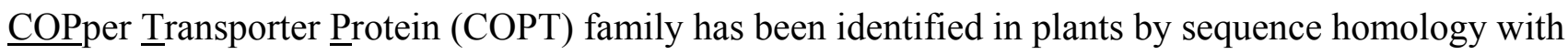
the eukaryotic $\mathrm{Cu}$ transporters named $\mathrm{Ctr}$ or by functional complementation in yeast (for reviews Peña et al. 1999; Labbé and Thiele, 1999; Harris 2000; Puig and Thiele 2002; Puig et al. 2007). The Arabidopsis genome contains six genes encoding COPT transporters, COPT1-6. The first one, COPT1, is the best characterized member of this $\mathrm{Cu}$ transporter family. It was identified by the ability of its cDNA to functionally complement a Saccharomyces cerevisiae ctrl $\triangle$ mutant defective in high-affinity $\mathrm{Cu}$ uptake. COPT1 transporter allows the entrance of $\mathrm{Cu}$ into cells from the exterior to the cytoplasm (Kampfenkel et al. 1995; Sancenón et al. 2003). All members of this protein family contain three predicted transmembrane (TM) segments and most posses an N-terminus methionineand histidine-rich putative metal binding domains (Puig and Thiele 2002; Klomp et al. 2003) (Fig. 2). Genetic data and in vivo uptake experiments have demonstrated that an extracellular methionine residue, located approximately 20 amino acids before TM1, and an MxxxM motif within TM2, are essential for $\mathrm{Cu}$ acquisition, and probably mediate metal coordination during transport. A symmetrical trimer organization with a novel channel-like architecture has been shown in the human Ctr1 transporter homolog to COPT members (Aller et al. 2004; Aller and Unger 2006).

Metal competition experiments suggest that Arabidopsis COPT1, as for other Ctr1 family members, is a high-affinity transporter with specificity for $\mathrm{Cu}^{+}$ion (Sancenón et al. 2003) with a $\mathrm{K}_{\mathrm{m}}$ in the lower micromolar range (Eisses and Kaplan 2002; Lee et al. 2002). COPT transporters do not use ATP for $\mathrm{Cu}$ import, but their transport ability is stimulated by extracellular $\mathrm{K}^{+}$. The COPT1 transporter is likely to be active in the cell membrane and its expression is negatively regulated by $\mathrm{Cu}$. The COPT1 gene is highly expressed in embryos, trichomes, stomata, pollen and roots tips. All of these cells are characterized by a lack of functional plasmodesmata, which blocks the acquisition of nutrients by a symplastic route. COPT 1 antisense plants have decreased Cu levels as a result of 
decreased $\mathrm{Cu}$ uptake and show sensitivity to $\mathrm{Cu}$ chelators. These plants have also a pollendevelopment defect and root-elongation phenotype, both of which are reversed by $\mathrm{Cu}$ feeding. Thus, its participation in root elongation, pollen development and apoplastic $\mathrm{Cu}$ transport has been proposed (Sancenón et al. 2004). COPT1 plays an important physiological role in root $\mathrm{Cu}$ acquisition and accumulation since it is required for growth under $\mathrm{Cu}$ limiting conditions.

Subsequent members of COPT family have been identified by sequence homology to COPT1 and yeast (Saccharomyces cerevisiae) complementation (Sancenón et al. 2003). The existence of three COPT groups according to the number of $N$-terminus methionine- and histidine- rich boxes has been proposed. The first one, including COPT1 and COPT2, displays the more high-affinity $\mathrm{Cu}$ transporter features being probably plasma membrane proteins. The second group includes the COPT3 and COPT5 transporters having only one methionine- and histidine- rich box, which shows partially level of both complementation and $\mathrm{Cu}$ transport rate. COPT3 and COPT5 probably participate in intracellular $\mathrm{Cu}$ transport. Putative target sequences to the chloroplast and the secretory pathway have been predicted for COPT3 and COPT5, respectively. COPT4 represents a third group showing high level expression in roots that lacks methionine residues and motifs essential for Ctr1mediated high-affinity $\mathrm{Cu}$ transport. These findings suggest a non-direct role in $\mathrm{Cu}$ transport (Sancenón et al. 2004) and its function in Cu homeostasis is currently questionated. An additional member of COPT family, named COPT6, has been identified recently. Further characterization will be necessary to know its putative role in $\mathrm{Cu}$ transport.

\subsection{2 $\mathrm{P}_{1 \mathrm{~B}}$-type ATPase transporters}

P-type heavy metal ATPases are involved in the transport of a range essential and potentially toxic metals (i.e., $\mathrm{Cu}^{+}, \mathrm{Cu}^{2+}, \mathrm{Zn}^{2+}, \mathrm{Cd}^{2+}, \mathrm{Pb}^{2+}$ ) across cell membranes (Solioz and Vulpe 1996; Palmgren and Axelsen 1998). They transport metals across membranes following the classical E1/E2 AlbersPost catalytical cycle (Külhbrandt 2004, Argüello et al. 2007). Sequence comparisons generally 
group $\mathrm{P}_{1 \mathrm{~B}}$-type ATPases into two further classes: $i$ ) those transporting monovalent cations as $\mathrm{Cu} / \mathrm{Ag}$ and ii) those transporting divalent cations as $\mathrm{Cd} / \mathrm{Pb} / \mathrm{Zn} / \mathrm{Co}$ (Axelsen and Palmgren 2001; Cobbet et al. 2003). Structurally, $\mathrm{P}_{1 \mathrm{~B}}$-type ATPases contain eight transmembrane (TM) segments with various cytoplasmic domains involved in enzyme phosphorylation (P-domain), nucleotide binding (Ndomain) and energy transduction (A-domain), domains that are common for all P-type ATPases (Fig. 2). Additionally, $\mathrm{P}_{1 \mathrm{~B}}$-ATPases show different features associated with their singular function in heavy metal transport such as $i$ ) metal transmembrane binding sites responsible for metal recognition and movement across the membrane permeability barrier, and ii) $\mathrm{N}$ - and C-termini metal binding domains with highly conserved $\mathrm{CxxC}$ motif that control the enzyme turnover rate without affecting metal binding to transmembrane transport sites (Argüello 2003; Argüello et al. 2007). The mechanism operating during metal delivery to metal transmembrane binding sites is still not clear but the requirement of conserved amino acid residues in the transmembrane region has been proposed (Argüello 2003; Argüello et al. 2007). More recently, the structure of two transmembrane transport sites with high metal affinity has been determined in a $\mathrm{P}_{1 \mathrm{~B}}$-ATPase transporting $\mathrm{Cu}^{+}$ (Argüello et al. 2008). Site I constituted by two cysteines in TM6 (CPC motif) and a tyrosine in TM7 and site II formed by asparagine in TM7 and methionine and serine in TM8. Both sites can be independently loaded with $\mathrm{Cu}$ but their simultaneous occupation is associated with enzyme turnover. It has been postulated that chaperone can deliver $\mathrm{Cu}^{+}$directly to the transmembrane metal-binding sites, suggesting that in this model the $\mathrm{N}$-terminus metal binding-site has a regulatory function without participating in metal transport (González-Guerrero and Argüello 2008; Chen-Chou 2008).

Plants differ significantly from other organisms in the number and selectivity of their $\mathrm{P}_{1 \mathrm{~B}}-$ ATPases (Williams and Mills 2005). For instance, the number of genes encoding $\mathrm{P}_{1 \mathrm{~B}}$-ATPases can vary among species. Arabidopsis genome encodes eight members of the $\mathrm{P}_{1 \mathrm{~B}}$-type ATPase subfamily, 
also known as HMA transporters (AtHMA1-AtHMA8), a number similar to other non-plant eukaryotic species, which have been characterized to some extent. These proteins differ in their structure, function and regulation but all of them are specialized in specific metal ion transport to cellular compartments and targets proteins (Baxter et al. 2003; Williams and Mills 2005). The rice (Oryza sativa L.) genome contains nine $P_{1 B}$-type ATPase genes and ten members of this subfamily have been identified in barley (Hordeum vulgare L.).

AtHMA1 to $A t$ HMA4 belong to the group implicated in divalent cations transport, and $A t$ HMA5 to $A t$ HMA8 act in transport of monovalent $\mathrm{Cu}^{+}$ions. Based on their amino acid sequences and topological arrangements, and combining this with their metal affinity the $\mathrm{P}_{1 \mathrm{~B}}$-ATPases (HMAs) have been classified into six subgroups $\left(\mathrm{P}_{1 \mathrm{~B}-1}-\mathrm{P}_{1 \mathrm{~B}-6}\right)$ (Argüello 2003; Argüello et al. 2007). The first member cloned in plants was PAA1 (AtHMA6) ( $\mathrm{P}_{1 \mathrm{~B}}$-type ATPase of Arabidopsis 1) from Arabidopsis thaliana L. (Tabata et al. 1997), which shows similarity to the cyanobacterial CtaA protein. Later, Shikanai et al. (2003) demonstrated that PAA1 (AtHMA6) is responsible for the delivery of $\mathrm{Cu}$ to chloroplasts, which provides the cofactor for the stromal $\mathrm{Cu} / \mathrm{ZnSOD}$ enzyme and for the thylakoid lumen protein plastocyanin. paal mutants have a high chlorophyll fluorescence phenotype arising from impaired photosynthetic electron transport apparently because of a deficiency in holoplastocyanin. The phenotype can be rescued by the addition of excess $\mathrm{Cu}$ to the growth medium. PAA2 (AtHMA8), closely related to PAA1 (AtHMA6), shows similarity to PacS transporter from cyanobacteria and transports $\mathrm{Cu}$ into the thylakoid lumen to supply plastocyanin (Abdel-Ghany et al. 2005b). A double paalpaa2 mutant resulted in seedling lethality, a more severe phenotype than that observed for plants defective for both genes, underlying the importance of $\mathrm{Cu}$ to photosynthesis (Weigel et al. 2003; Abdel-Ghany et al. 2005b). The phenotypes of paal and paa2 mutants were reverted by addition of exogenous $\mathrm{Cu}$ but not of the paalpaa2 double mutant, suggesting that an alternative lower-affinity pathway for $\mathrm{Cu}$ delivery can exist in chloroplasts. 
Recently, the homolog of PAA2 (AtHMA8) in soybean (Glycine max L. var. Corsoy) named GmHMA8 has been identified and localized in the thylakoid membrane (Bernal et al. 2007b).

Proteomic analyses of the Arabidopsis chloroplast envelope identified AtHMA1 as a new candidate for the alternative $\mathrm{Cu}$ transport into this organelle (Seigneurin-Berny et al. 2006). AtHMA1 localizes in chloroplast envelope and affects $\mathrm{Zn}$ - and $\mathrm{Cu}$-uptake activity when expressed in yeast. It is worth mentioning that the $A t \mathrm{HMA} 1$ protein does not contain the $\mathrm{MxCxxM} \mathrm{N}$-terminus $\mathrm{Cu}^{+}$ binding motifs (Fig. 2), but instead, it is histidine rich at the N-terminus domain, suggesting that it may transport $\mathrm{Cu}^{2+}$ rather than $\mathrm{Cu}^{+}$. Characterization of hmal mutants revealed lower $\mathrm{Cu}$ content in chloroplasts and a reduction of the chloroplast $\mathrm{Cu} / \mathrm{ZnSOD}$ activity, but normal plastocyanin content, suggesting that AtHMA1 could deliver divalent ions including $\mathrm{Cu}^{2+}$ and $\mathrm{Zn}^{2+}$ to $\mathrm{Cu} / \mathrm{ZnSOD}$ in plastids. The idea that $\mathrm{Cu}^{2+}$ may be present in the space between both chloroplast envelopes is supported by the existence of the chloroplast $\mathrm{Cu}^{2+}$-binding protein AtCutA (Burkhead et al. 2003) in this location. However, the responsible transporters for this alternative transport activity in thylakoids have not been described yet. Furthermore, AtHMA1 may have specific functions in plants grown under adverse light conditions (Seigneurin-Berny et al. 2006).

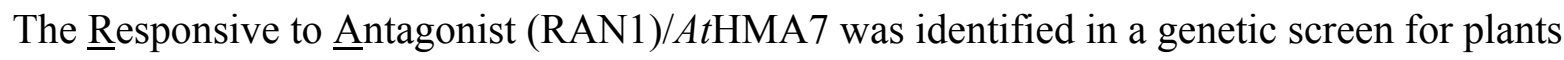
with an unusual response to the ethylene antagonist trans-cyclooctene, underscoring the critical role of $\mathrm{Cu}$ in the ethylene-signalling pathway (Hirayama et al. 1999). This role is explained by the fact that ethylene receptors are $\mathrm{Cu}$-dependent proteins (Rodríguez et al. 1999; Hirayama and Alonso 2000). In Arabidopsis, RAN1 (AtHMA7) was the first functionally characterized heavy metal ATPase. RAN1 (AtHMA7) is involved in ethylene signalling by supplying $\mathrm{Cu}$ at the endoplasmic reticulum, where it is required for the formation of functional ethylene receptors (Woeste and Kieber 2000; Chen et al. 2002). The plant hormone ethylene is an important signal in many abiotic stress situations but also in plant pathogen interaction. RAN1 (AtHMA7) has also been found in rapeseed 
(Brassica napus), BnRAN1, (Southron et al., 2004). Among the rice $\mathrm{P}_{1 \mathrm{~B}}$-ATPases, OsHMA9 was found to form a subclass with RAN1 (AtHMA7). The recent characterization of OsHMA9 indicated that it plays a role in $\mathrm{Cu}$ detoxification acting as an efflux pump in the plasma membrane (Sichul et al. 2007). Mutant oshma9-1 and oshma9-2 plants exhibited the phenotype of increased sensitivity to high levels of $\mathrm{Cu}$, and also $\mathrm{Zn}$ and $\mathrm{Pb}$. The OsHMA9 gene was mainly expressed in vascular tissues, including xylem and phloem and weakly expressed in mesophyll tissues. In developing tissues, expression was strong in anthers, suggesting a putative role in metal delivery to rice anthers. The importance of metal transport in anthers has been previously reported.

The Arabidopsis AtHMA5, the closest homolog of RNA1 (AtHMA7) in the $\mathrm{P}_{1 \mathrm{~B}}$-type ATPase subfamily, is strongly and specifically induced by $\mathrm{Cu}$ in whole plants (Fig. 2). The hma5 T-DNA insertion mutants are hypersensitive to $\mathrm{Cu}$ and $\mathrm{HMA} 5$-defective plants accumulate $\mathrm{Cu}$ in roots to a greater extent than wild-type plants, suggesting its key role in transmembrane transport, and particularly in root $\mathrm{Cu}$ detoxification (Andrés-Colás et al. 2006). This phenotype is the opposite of that observed for the COPT antisense lines, supporting the notion that COPT1 and AtHMA5 transport $\mathrm{Cu}$ in opposite directions. AtHMA5 is mostly expressed in roots, flowers and pollen. The specific interaction of AtHMA5 with two different ATX1-type chaperones, ATX1 and CCH, in Arabidopsis thaliana has been demonstrated. Although further experiments are necessary to confirm the fact, it has been proposed that $A t \mathrm{HMA} 5$ could be involved in $\mathrm{Cu}$ efflux at specific root cells and its overexpression in plants could be a strategy for improving $\mathrm{Cu}$ detoxification under $\mathrm{Cu}$ excess.

\subsubsection{Copper chaperones}

The $\mathrm{Cu}$ chaperones belong to a new family of cytosolic, soluble, low-molecular-weight metalreceptors proteins named metallochaperones that are involved in the intracellular trafficking of metal ions and insert the $\mathrm{Cu}$ into the active sites of specific partners, $\mathrm{Cu}$-dependent enzymes (O'Halloran 
and Culotta 2000; Huffman and O'Halloran 2001). The limited solubility and high reactivity of $\mathrm{Cu}$ inside the cell requires the participation of these specialized proteins that prevent inappropriate $\mathrm{Cu}$ interaction with other cellular components. $\mathrm{Cu}$ chaperones are conserved in most eukaryotes, but specific characteristics seem to emerge in plants. In yeast, the P-type ATPase transporter named $\mathrm{Ccc} 2 \mathrm{p}$ interacts with a small cytosolic $\mathrm{Cu}$ chaperone named Antioxidant1p (Atx1), which delivers $\mathrm{Cu}$ to the $\mathrm{Ccc} 2 \mathrm{p}$ by direct protein-protein interaction. Arabidopsis has two homologs of the yeast

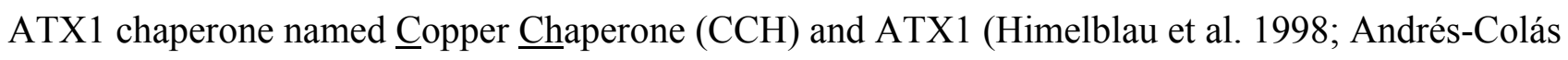
et al. 2006). $\mathrm{CCH}$ has been the most extensively studied of the $\mathrm{Cu}$ chaperones in plants (Mira et al. 2001a, b). The CCH chaperone exhibits the conserved features of the ATX1-type metallochaperone family such as typical lysine residues, overall $\beta \alpha \beta \beta \alpha \beta$ fold structure and an $\mathrm{MxCxxC} \mathrm{Cu}^{+}$-binding motif in the $\mathrm{N}$-terminus (Pufahl et al. 1997). However, $\mathrm{CCH}$ also presents a plant-exclusive Cterminal domain with special structural characteristics (Mira et al. 2001a,b; Mira et al. 2004) that makes $\mathrm{CCH}$ unique and distinct from the non-plant ATX1-type chaperones. $\mathrm{CCH}$-like C-terminus domains have been only found in higher plants, suggesting a regulatory role for that. Both the $\mathrm{CCH}$ and ATX1 chaperones complement the yeast atx 1 mutant and interact with the $N$-terminus of AtHMA5 (Andrés-Colás et al. 2006). However, the $C$-terminus of $\mathrm{CCH}$ has a negative effect on its interaction with $\mathrm{AtHMA5}$. The plant $\mathrm{CCH}$ gene expression has been related to oxidative stress and senescence, when the plant reallocates nutrient resources. High levels of $\mathrm{CCH}$ expression were found in Arabidopsis stems and vascular cells that lack nuclei. A plant-specific role in $\mathrm{Cu}$ symplastic transport through the plasmodesmata during senescence associated with nutrient mobilization has been proposed for this extra $\mathrm{C}$-terminus domain of $\mathrm{CCH}$. Expression of $\mathrm{CCH}$ increases by oxidative stress, senescence, and $\mathrm{Cu}$ deficiency. A $\mathrm{CCH}$ chaperone has been also identified by differential display in tomato $(\mathrm{LeCCH})$ infected with the fungal pathogen Botrytis cinerea (Company and González-Bosch 2003) suggesting an interesting relationship between $\mathrm{Cu}$ homeostasis and plant defence responses. 
The COX17 chaperone shares sequence similarity to $\mathrm{COX} 17$ from yeast that might mediate the delivery of $\mathrm{Cu}$ to the mitochondria for the assembly of a functional cytochrome-c oxidase complex (Balandin and Castresana 2002). In this manner COX17 would contribute to the increase in activity of specific enzymes that are required to preserve organelle functionality in a number of biotic and abiotic stress situations.

Despite their role in $\mathrm{Cu}$ homeostasis, neither $\mathrm{CCH}$ nor RAN1 (AtHMA7) are induced by $\mathrm{Cu}$ treatment, indicating that they might be more important in helping cells cope with $\mathrm{Cu}$ deficit than $\mathrm{Cu}$ excess. In contrast, activation of $\mathrm{AtCOX17}$ gene expression in response to $\mathrm{Cu}$ treatment might be an indication of a function like metallothioneins, which are also induced by high concentrations of metals (Zhou and Goldsbrough 1995). Nevertheless, further experimental support is necessary to establish the function of these proteins.

The CCS gene, homolog of the yeast $C \operatorname{cs} 1 p / L y s 7 p$ gene, encoded a protein that delivers $\mathrm{Cu}$ to the $\mathrm{Cu} / \mathrm{ZnSOD}$ by a protein-protein interaction. It has been identified in tomato (LeCCS) (Zhu et al. 2000), Arabidopsis thaliana (Wintz and Vulpe 2002), potato (Solanum tuberosum L.; StCCS) (Trindade et al. 2003), maize (ZmCCS) (Ruzsa and Scandalios 2003) and soybean ( $\mathrm{GmCCS}$ ) (Sagasti S, Bernal M, Picorel R, Yruela I, unpublished results). AtCCS has a predicted chloroplast targeting sequence but dual localization in both cytosol and plastids (Chu et al. 2005). Therefore is possible that $A t \mathrm{CCS}$ delivers $\mathrm{Cu}$ to both cytosolic and chloroplastic $\mathrm{Cu} / \mathrm{ZnSOD}$ enzymes, perhaps using an alternative translation start site. It has been shown that $A t \mathrm{CCS}$ is $\mathrm{Cu}$ up-regulated and co-regulated with cytosolic and chloroplastic $\mathrm{Cu} / \mathrm{ZnSOD}$ targets indicating an important role in the regulation of oxidative stress protection. An up-regulation of $A t C C S$ mRNA has been also found in response to senescence. Additionally, AtCCS, and both cytosolic and chloroplastic $\mathrm{Cu} / \mathrm{ZnSODs}$ were downregulated in response to $\mathrm{Cu}$ deficiency. It has been also proposed that $A t C C S$ expression is regulated to allow the most optimal use of $\mathrm{Cu}$ for photosynthesis (Abdel-Ghany et al. 2005a).

StCCS gene expression was induced by auxin which is known to play a role in different 
stages of potato (Solanum tuberosum) development. Auxins have a promoting effect on cell elongation/expansion. Surprinsingly, potato (Solanum tuberosum L.) plants sprayed with $\mathrm{CuSO}_{4}$ did not respond with a significant change in StCCS expression (Trindade et al. 2003). This is consistent with the inhibition of StCCS gene expression observed when potato plants were grown in vitro in media supplemented with $10 \mathrm{mM} \mathrm{CuSO}_{4}$. This surprised finding may be explained if the presence of a chaperone would not be required for the incorporation of $\mathrm{Cu}$ in the $\mathrm{Cu} / \mathrm{ZnSOD}$ when $\mathrm{Cu}$ is present at high concentrations in leaves.

\subsubsection{ZIP transporters}

ZIP proteins belong to divalent metal transporters family and generally contribute to metal ion homeostasis through the transport of cations into the cytoplasm (Colangelo and Guerinot 2006; Puig et al. 2007). They contain eigth transmembrane (TM) domains and a histidine-rich variable loop between TM3 and TM4. IRT1 (Iron-Regulated Transporter 1) is the best characterized member of ZIP family in plants. Fe acquisition in Arabidopsis roots under Fe deficiency mostly depends on AtIRT1, which is considered the major Fe transporter at the root surface in Arabidopsis thaliana. The closely OsIRT1 appears to play similar role in Fe uptake under Fe limiting conditions in rice. The ZIP family contains 14 additional members in Arabidopsis (Mäser et al. 2001). AtZIP2 and AtZIP4 complement growth defects of yeast $\mathrm{Cu}$ and $\mathrm{Zn}$ transport mutants (Grotz et al. 1998; Wintz et al. 2003). Expression of both genes is up-regulated in Arabidopsis by deficiency in $\mathrm{Cu}$ and $\mathrm{Zn}$, but not in Fe. It has been proposed that AtZIP2 participates in $\mathrm{Cu}$ acquisition by Arabidopsis roots. Although the role of these proteins in plant $\mathrm{Cu}$ transport still requires further characterization, the preference that ZIP family members show for divalent metals suggest that ZIP2 and ZIP4 proteins may transport $\mathrm{Cu}^{2+}$ ions.

Six cDNA encoding ZIP family members have been identified in the model legume 
Medicago truncatula L.and tested for the ability to complement yeast metal-uptake mutants (LópezMillán et al. 2004). A role in metal homeostasis has been proposed based on expression analysis of mRNA levels in response to metal supply.

\subsubsection{Nramp transporters}

Nramp family members are implicated in the transport of several divalent metal ions. In plants, investigations of Nramp family were largely restricted to rice (Oryza sativa) where three members were identified, OsNramp1, OsNaramp2 and a partial length OsNramp3 (Belouchi et al. 1995; 1997). Subsequently, two Arabidopsis genes were identified (Alonso et al. 1999) which showed similarity to Nramps. More recently, three additional genomic sequences from Arabidopsis with homology to Nramps have been found named AtNramp1, AtNramp3 and AtNramp4. Comparisons of pair wise similarities between each of these genes suggests that the plant Nramps can be broadly divided into two groups: 1) OsNramp1, OsNramp3 and AtNramp5 which share high similarity and 2) OsNramp2, AtNramp1, AtNramp2, AtNramp3 and AtNramp4, which have lower similarity to group (1). This finding could suggest the possibility of subgroups that may vary in their substrate specificity, although this remains to be demonstrated. As with other members of this family, the plant Nramp proteins have twelve predicted transmembrane domains, however, it also possesses a long intracellular $C$-terminus tail which is unique to the Nramp proteins. A transport function for the plant Nramp homologues remains to be formally demonstrated; however there is good evidence from yeast studies for a role of the Nramp proteins in divalent cation transport. In Arabidopsis Nramp1 (AtNramp1) confers tolerance to toxic concentrations of external Fe (Curie et al. 2000). Homologues

of Nramp family have been also identified in soybean proposing to be involved in $\mathrm{Fe}^{2+}$ transport and Fe homeostasis in the nodule to support symbiotic $\mathrm{N}_{2}$ fixation (Kaiser et al. 2003). However, they have also been shown to be mediating the uptake to other metal ion such as $\mathrm{Cu}$ in yeast. Therefore a similar function in plants should be not dismissed. 
2.3.6 Mugineic acid and nicotianamine.

Since very little metal in plants is assumed to exist as free ions, a number of small organic molecules have to be implicated in metal ion homeostasis as metal ion ligands or chelators in order to improve acquisition and transport of metal ions with low solubility, and immobilization for metal tolerance and storage. Among these ligands mugineic acid (MA) and nicotianamine (NA) have been shown to participate in the transport of essential metals such as $\mathrm{Cu}, \mathrm{Fe}, \mathrm{Mn}$, Ni or Zn. Nicotianamine (NA), which is a precursor of mugineic acid (MA), is an ubiquitous metal-chelator in all plants and, like MA, is believed to play a primary role in metal homeostasis (Haydon and Cobbet 2007). In vitro, NA is able to form stable complexes with $\mathrm{Mn}, \mathrm{Fe}, \mathrm{Co}, \mathrm{Zn}, \mathrm{Ni}$ and $\mathrm{Cu}$, in increasing order of affinity (Curie et al. 2009). The stability of all metal-NA complexes is maximal at $\mathrm{pH} 6.5$ indicating that NA would be more likely a symplastic chelator of metals but among essential metals $\mathrm{Cu}$ is the exception as the $\mathrm{Cu}-\mathrm{NA}$ complex being very stable in mild acidic conditions. This fact favours the possible occurrence of $\mathrm{Cu}-\mathrm{NA}$ complex in an apoplastic environment such as the xylem. NA is synthetisized by nicotianamine synthase (NAS) from S-adenosyl-L-methionine. The first evidence for a role of $\mathrm{NA}$ in metal transport came from $\mathrm{Cu}$ - and $\mathrm{Fe}$ - related phenotypes associated with the NA synthesisdefective chloronerva tomato mutant, which showed interveinal chlorosis (Ling et al. 1996; Mori 1999). Later, studies in NA-defective tobacco (Nicotiana sp.) plants pointed to the essentiality of NA for metal transport in veins and interveinal areas, and for reproductive growth and fertility. Nicotianamine synthase $(N A S)$ genes were up-regulated in roots and shoots of plants grown under $\mathrm{Cu}, \mathrm{Fe}$ or $\mathrm{Zn}$ deficiency. Recent evidence for the role of NA in plants comes from depletion of NA in tobacco (Nicotiana sp.) by transgenic overexpression of Nicotianamine aminotransferase (NAAT) from barley. The levels of $\mathrm{Cu}, \mathrm{Fe}$ and $\mathrm{Zn}$ decreased in leaves and floral organs of transgenic plants, suggesting a role for NA in long-distance translocation of these metals. In a reciprocal experiment, overexpression of barley $N A S$ in transgenic tobacco (Nicotiana sp.) lead to increased $\mathrm{Cu}, \mathrm{Fe}$ and $\mathrm{Zn}$ content in leaves and flowers and enhanced the Fe and $\mathrm{Zn}$ content of pollen and seeds, further 
supporting a role for NA in transport of these metals (Takahashi et al. 2003). This could be consistent with NA should complex $\mathrm{Cu}, \mathrm{Fe}$ and $\mathrm{Zn}$ in the phloem and $\mathrm{Cu}$ and $\mathrm{Zn}$ in the xylem for their translocation from roots to shoots (von Wiren et al. 1999). The finding that Cu-NA complex is completely stable at the $\mathrm{pH}$ of xylem sap (pH 5-6) supports this assumption (Curie et al. 2009).

\subsubsection{YSL transporters}

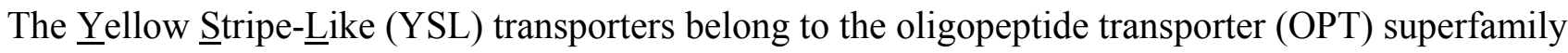
(Curie et al. 2001; Curie et al. 2009), which transport tri-, tetra-, penta- and hexapeptides (Yen et al. 2001). YSL proteins are also believed to mediate the uptake of metals that are complexed with plantderived phytosiderophores (PS) or nicotianamine (NA) (Colangelo and Guerinot 2006). Thus, the assumption that the members of the OPT family transport only peptides is being challenged since some OPT protein may also be capable of divalent metal ions transport. The best-studied member of this family is YS1 from maize (Roberts et al. 2004; Schaaf et al. 2004). ZmYS1 protein accumulates in roots and leaves of Fe-deficient plants and functions as a proton-coupled symporter to transport Fe-PS and may also play a role in the homeostasis of $\mathrm{Cu}, \mathrm{Zn}$ or $\mathrm{Ni}$ as mugineic (MA)-complexes. On the basis of sequence similarity to ZmYS1, A. thaliana has eight predicted YSL proteins. Considering that non-grasses plants do not produce or use PS, AtYSL proteins most probably transport metal-NA complexes. Two family members, AtYSL1 and AtYSL2, have recently been studied is some detail. AtYSL2 transcript accumulation increases under conditions of Fe sufficiency or Fe resupply, and AtYSL2 transcript levels also respond to $\mathrm{Cu}$ and $\mathrm{Zn}$ (DiDonato et al. 2004; Schaaf et al. 2005). The expression of AtYSL2 in metal-uptake-defective yeast strains mediated the uptake of Fe-NA and Cu-NA. Localization of Arabidopsis YSL2 in root endodermis and pericycle cells facing the meta-xylem tubes has suggested its participation in lateral movement of $\mathrm{Fe}$ and/or $\mathrm{Cu}$ within the veins (Schaaf et al. 2005). These proteins seem to be involved in the unloading of metal-NA from vasculature into developing tissues, in immobilization of metal-NA from senescent leaves and in an 
efficient loading of metal-NA into seeds.

AtYSL1 transcript levels increase in response to high Fe conditions (Le Jean et al. 2005). Arabidopsis YSL1-defective mutants contain lower levels of Fe-NA in their seeds and display a transient defect in germination that can be rescued by Fe supply. It has been shown that AtYSL1 and AtYSL3 were up-regulated during leaf senescence. The ysllysl3 double knockout mutants, which exhibit interveinal chlorosis in leaves caused by decreased Fe levels and reduced fertility as a consequence of defective anther and embryo development were less efficient in mobilizing metals, especially $\mathrm{Cu}$, from senescent leaves. These results and YSL1/YSL3 expression in the vasculature of shoots and reproductive organs suggest a function in $\mathrm{Cu}$ delivery among other metals from vascular tissues, as well as in Fe-NA delivery to seeds (Waters et al. 2006). AtYSL2 and AtYSL3 are differentially expressed under metal deficiencies, and heterologous expression of AtOPT3 in yeast suggests that it can transport $\mathrm{Cu}^{2+}, \mathrm{Mn}^{2+}$, and $\mathrm{Fe}^{2+}$ (Wintz et al. 2003).

The rice (Oryza sativa) genome contains 19 putative OsYSL genes. OsYSL2 has been shown to transport $\mathrm{Fe}^{2+}-\mathrm{NA}$ and $\mathrm{Mn}^{2+}-\mathrm{NA}$ complexes but not $\mathrm{Fe}^{3+}-\mathrm{NA}$. A role in the transport of divalent cations in the phloem has been suggested (Koike et al. 2004; Colangelo and Guerinot 2006). Current investigations point out the role of YSL proteins in long-distance metal-NA chelate transport and development of pollen grains and seeds (Curie et al. 2009) but further studies are necessary to clarify if specific members of YSL family have substrate specificity.

\subsection{Regulatory mechanisms}

In plants, the regulatory mechanism of gene expression is a relatively new area of research.

Particularly, there are still little indications of how genes encoding metal transporters are regulated in higher plants. This could occur potentially at the transcriptional level (control on initiation rates, differential mRNA splicing, mRNA stability) or at the post-translational level (targeting, stability). Many metal transporters in other organisms are regulated at the transcriptional level by extracellular 
metal concentrations via transcription factor proteins (Radisky 1999). Studies in model organisms such as the green alga Chlamydomonas reinhardtii and the yeast Saccharomyces cerevisiae outlined a number of principles of metal regulation. Metal-sensing transcription factors controlling the transcription of target genes are a common feature in metal acquisition. These are examples for very direct metal-dependent regulation, not requiring upstream signal transduction cascades. For instance, under $\mathrm{Cu}$ deficiency the $\mathrm{Cu}$-binding Mac $1 \mathrm{p}$ (metal-binding activator 1) transcription factor of $S$. cerevisiae binds as a homodimer to copper-responsive sequence elements $(\mathrm{CuRE})$ in the promoters of the genes $S c C t r 1$ and $S c C t r 3$, which encode $\mathrm{Cu}^{+}$uptake systems (Labbe et al. 1997; Zhu et al. 1998; Rutherford and Bird 2004; Krämer and Clemens 2006). Mac 1p is able to bind four $\mathrm{Cu}^{+}$ions in a poly-copper cluster within its transactivation domain. The binding of $\mathrm{Cu}^{+}$to $\mathrm{Mac} 1 \mathrm{p}$ triggers an interaction between the transactivation and DNA binding domains of Mac 1p, inhibiting the functions of both domains. Under conditions of $\mathrm{Cu}$ excess, the $\mathrm{Cu}$-dependent transcriptional activator ScAcelp is activated by the binding of four $\mathrm{Cu}^{+}$ions and activates the transcription of genes involved in the protection of yeast cells from $\mathrm{Cu}$ toxicity, such as the gene encoding the $\mathrm{Cu}$ buffering cysteine-rich Cup1 protein (Rutherford and Bird 2004).

In plants, depending on $\mathrm{Cu}$ status, a mechanism of $\mathrm{Cu}$-responsive transcriptional repression via SBP-related transcription factors (SPL) that bind to GTAC sequences within the promoter region regulates the replacement of chloroplastic FeSOD by $\mathrm{Cu} / \mathrm{ZnSOD}$ in response to $\mathrm{Cu}$ by directly repressing the transcription of the $F e S O D$ gene and indirectly inducing the transcription of the CuZnSOD (Nagae et al. 2008).

Although numerous animal and human genes are alternatively spliced (Green 1991), the role of this type of regulatory mechanism of gene expression in plants is a relatively new area of research (Kazan 2003). The great majority of alternatively spliced genes in Arabidopsis thaliana encode proteins with regulatory functions. Additionally, genes associated with various stress (biotic, water, 
light, salt, wounding, heavy metal, heat) responses seem to be particularly prone to alternative splicing in both animals and plants (Kazan 2003). Among those, AtCutA mRNA that encodes a chloroplast protein involved in $\mathrm{Cu}$ tolerance in Arabidopsis is regulated by alternative splicing (Burkhead et al. 2003). $P_{1 B}$-ATPases seem to be also alternatively spliced, at least in certain plants. Bernal (2006a) demonstrated that GmHMA8, a member of the soybean $\mathrm{P}_{1 \mathrm{~B}}$-ATPases subfamily, is subject of alternative splicing, whereby retention of an intron yield a non-spliced (NSP) transcript named NSP-GmHMA8. The putative non-spliced NSP-GmHMA8 protein contains six transmembrane (TM) domains, two TMs shorter than typical $\mathrm{P}_{1 \mathrm{~B}}$-ATPases including GmHMA8. In humans, there is evidence that splicing regulates both the Menkes (ATP7A/MNK) and the Wilson (ATP7B/WMN) $\mathrm{Cu}^{+}-\mathrm{P}_{1 \mathrm{~B}}$-ATPases highly homologues to GmHMA8. Generally, many spliced products in humans show tissue-specific expression (Lutsenko et al. 2007).

Another important level of metal regulation is the metal-dependent regulation of transcript stability. $\mathrm{Cu}$-dependent transcriptional regulation has been shown in the unicellular green alga Chlamydomonas reinhardtii. Apoplastocyanin is rapidly degraded when $\mathrm{Cu}$ is not available for the formation of holoplastocyanin, probably through a non-specific pathway (Merchant and Bogorad 1986a,b). Thus, the availability and insertion of the metal cofactor into apoplastocyanin controls the stability of the translation product in the chloroplast of $C$. reinhardtii. Although not all apometalloproteins are unstable, the insertion of metal ion cofactors is likely to be an important factor controlling the activity and/or stability of proteins, and possibly of biological processes (Krämer and Clemens 2006).

Additionally, it has been shown that $\mathrm{Cu}$ regulates the expression of certain members of $\mathrm{P}_{1 \mathrm{~B}}{ }^{-}$ ATPases, COPT transporters, and $\mathrm{Cu}$ chaperones. For instance, the expression of AtHMA5 in Arabidopsis, and OsHMA5 and OsHMA9 in rice, $P_{1 B}$-ATPases involved in $\mathrm{Cu}$ detoxification, is stimulated by excess $\mathrm{Cu}$ at the transcriptional level (Andrés-Colás et al. 2006; Sichul et al. 2007). On 
the contrary, excess $\mathrm{Cu}$ reduces the transcript level of PAA2 (AtHMA8) and GmHMA8 (Schiavon et al. 2007; Bernal 2006a). COPT1 mRNA levels increase when Cu is limited (Sancenón et al. 2003). Concerning $\mathrm{Cu}$ chaperones, AtCOX17 expression was up-regulated and AtATX1 expression was down-regulated in response to excess $\mathrm{Cu}$ supply (Baladin and Castresana 2002; Schiavon et al. 2007). By contrast, $C C S$ expression was not significantly influenced by $\mathrm{Cu}$ in Arabidopsis (Schiavon et al. 2007) whereas the accumulation of $C C S$ mRNA was strongly increased in soybean (Sagasti S, Bernal M, Picorel R, Yruela I, unpublished results).

In higher plants, there is little evidence for the post-transcriptional regulation of metal homeostasis proteins. However, there is solid evidence for the regulation of sub-cellular protein localization and stability in yeast and humans. Thus, it is likely that similar mechanisms operate in higher plants. An example of this post-transcriptional mechanism of metal regulation is the metaldependent re-localization or degradation of metal transport proteins. The ATP7A/MNK $\mathrm{P}_{1 \mathrm{~B}}$-ATPase responsible for Menkes disease in humans, and highly homologue to PAA2 (AtHMA8) and GmHMA8 transporters in plants, exhibits a Cu-dependent subcellular localization. The protein was proposed to cycle continuously between the Golgi and the plasma membrane. Under most conditions the major proportion of the ATP7A/MNK protein localizes predominantly to the trans-Golgi, supplying $\mathrm{Cu}$ to the lumen of this compartment. Under exposure to high $\mathrm{Cu}$ concentrations, localization is shifted towards the plasma membrane, where the bulk of this transporter exports $\mathrm{Cu}$ to the exterior of the cell. Furthermore, in Cu-deficient cells, the human $\mathrm{Cu}$ uptake transporter $h \mathrm{Ctr} 1$, highly homologue to COPT1 in plants, localizes to the plasma membrane, but undergoes $\mathrm{Cu}-$ stimulated endocytosis under $\mathrm{Cu}$ resupply. Two putative $\mathrm{Cu}$-binding methionine-rich sequence elements of $h \mathrm{Ctr} 1$ are involved in the regulation of endocytosis, suggesting that direct $\mathrm{Cu}$ sensing by hCtr1 may be controlling its localization (Guo et al. 2004).

Plants can be postulated to contain specific metal sensors that detect changes in metal status (deficiency or excess) and trigger signalling cascades that activate the appropriate responses. In 
higher plants, the signal transduction pathways involved have not been identified yet. Jonak et al. (2004) observed that toxic concentrations of $\mathrm{Cu}$ activated mitogen-activated protein kinases (MAPKs) in Medicago sativa seedlings, suggesting that MAPK pathways are activated in response to excess $\mathrm{Cu}$. MAPKs are involved in signal transduction induced by heavy metals and protein phosphorylation events. It remains to be established to which extent the activation of the respective MAP kinase cascades is metal-dependent or an effect of oxidative stress.

Recently, several exciting findings have revealed the regulation of micro-RNAs (miRNAs) expression by specific nutrient stresses (Chiou 2007). The novel function for miRNAs in regulating plant adaptive responses to nutrient stresses opens up an interesting field to research. The role of miR398 in the expression patterns of CSD1 and CSD2 mRNAs has been reported (Sunkar et al. 2006). Particularly, they show that miR398 expression is downregulated transcriptionally by oxidative stresses, and this downregulation is important for posttranscriptional CSD1 and CSD2 mRNA accumulation and oxidative stress tolerance. Transgenic A. thaliana plants overexpressing a miR398-resistant form of CSD2 accumulate more CSD2 mRNA than plants overexpressing a regular CSD2 and are consequently much more tolerant to high light, heavy metals, and other oxidative stresses. Evidence that several miRNA families mediate the regulation of $\mathrm{Cu}$-containing proteins in A. thaliana in response to $\mathrm{Cu}$ status has been recently reported (Yamasaki et al. 2007, Abdel-Ghany and Pilon 2008). The transcription of $m i R 398$ is repressed by $\mathrm{Cu}$ and $m i R 398$ mediates downregulation of chloroplastic $\mathrm{Cu} / \mathrm{ZnSOD}(\mathrm{CSD} 2)$ in $A$. thaliana in response to changes in a low range of $\mathrm{Cu}$ levels $(0.2-0.5 \mu \mathrm{M})$ (Yamasaki et al. 2007), indicating that miR398 is rather involved in a response to $\mathrm{Cu}$ limitation. A multiple copies of GTAC sequences were found in miR398 promoter sequences suggesting that $\mathrm{Cu}$ promotes the expression of the chloroplastic $\mathrm{Cu} / \mathrm{ZnSOD}$ (CSD2) posttranscriptionally by repressing the transcription of $m i R 398$ through GTAC sequences motif (Nagae et al. 2008). This GTAC sequence-dependent transcriptional regulatory mechanism by $\mathrm{Cu}$ seems to be conserved in land plants. The down-regulation of chloroplastic $\mathrm{Cu} / \mathrm{ZnSOD}$ (CSD2) on 
low $\mathrm{Cu}$ would contribute to maintaining a $\mathrm{Cu}$ pool for plastocyanin allowing plants to save $\mathrm{Cu}$ for essential functions such as photosynthetic electron transport (Yamasaki et al. 2007). More recently, Abdel-Ghany and Pilon (2008) have found that miR397, miR408 and miR857 together regulate other $\mathrm{Cu}$-containing proteins such as plantacyanin, and a number of laccases. These authors have proposed that $\mathrm{Cu}$ related miRNAs are used in response to avoid $\mathrm{Cu}$ deficiency since they are up-regulated already in a condition where symptoms of deficiency are still absent and where plastocyanin function is not compromised.

\subsubsection{Responses to copper deficiency}

$\mathrm{Cu}$ can be limiting to plant productivity when below $5 \mu \mathrm{gg}^{-1}$ dry weight. Cu-deficient plants show changes in the expression of a series of genes and activation of morphological changes either in root or leaf architecture. Typical symptoms of $\mathrm{Cu}$ deficiency appear first at the tips of young leaves and then extend downward along the leaf margins. The leaves may also be twisted or malformed and show chlorosis (i.e., loss of chlorophyll) or even necrosis; the overall biomass of affected plants is subsequently reduced. These symptoms are known for a long time (for review see Marschner 1995; Küpper and Kroneck 2005) and can be explained in view of the roles of $\mathrm{Cu}$ in plant metabolism. Thus, the lack of $\mathrm{Cu}$ reduces PSI electron transport due to decreased formation of plastocyanin (Baszynski et al. 1978; Shikanai et al. 2003), which is the major target of $\mathrm{Cu}$ deficiency in photosynthesis. Decrease in PSII activity was also observed in Cu-deficient chloroplasts (Droppa et al. 1987; Henriques 1989). Droppa et al. (1987) concluded that severe $\mathrm{Cu}$ deficiency changes the thylakoid membranes and modifies the ambient of the PSII acceptor side. They also noticed the absence of a $29 \mathrm{kDa}$ polypeptide, which is probably a component of CP29, a minor chlorophyll a/b binding protein of PSII. Cu-deficient plants show disintegration of the thylakoid membranes of chloroplasts (Baszynski et al. 1978; Henriques 1989) as well as decreased pigment (chlorophylls and carotenoids) content, reduced plastoquinone synthesis and lower unsaturated C18 fatty acids contents 
(Barón et al. 1992). Availability of $\mathrm{Cu}$ also affects $\mathrm{Cu} / \mathrm{ZnSOD}$ enzyme diminishing their expression and activity.

Current knowledge establishes that at least three different molecular strategies can be distinguished in response to $\mathrm{Cu}$ deficiency in plants. The first one is conducted to improve metal acquisition and includes increased expression of metal reductases and high-affinity transporters. The second one consists in prioritizing the use of metals in essential versus non-essential pathways. Finally, if metalloproteins with different metallic ligands perform similar or overlapping functions, a specific metalloprotein can be substituted by another when its metal is deficient (Puig et al. 2007). The up- and down- regulation of genes directing the events mentioned above involve a series of molecular mechanisms that begin with the plant "sensing" the deficiency and then transmitting the signal along transduction pathways through the plant vascular system. Signals between the aerial parts of the plants, including the apical meristem, and the roots lead to the activation or inactivation of transcription factors that influence expression of specific genes. Thus, plants respond to a change in metal supply by marked alterations in their transcriptome. Genetic and biochemical studies in model organisms (i.e., the green alga $C$. reinhardtii) have established that transcriptional regulation control is the primary response to $\mathrm{Cu}$ deficiency. The up-regulation of genes in response to $\mathrm{Cu}$ limitation in Chlamydomonas (i.e., cytochrome $c_{6}, C y t c_{6}$, and coproporphyrinogen III oxidase, $C P X 1)$ is dependent on Cu-responsive elements (CuREs) in the $5^{\prime}$ upstream region of $\mathrm{Cu}$-deficiency induced genes, with critical GTAC core sequences as responsible for transcription activation of genes under deficiency conditions (Quinn et al. 2000; 2002). Based on a genetic screen, Eriksson et

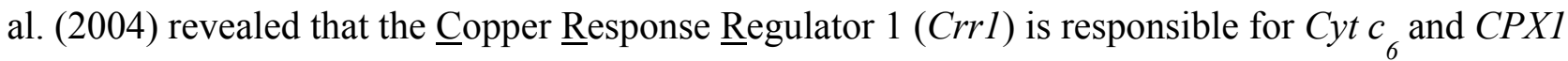
activation upon $\mathrm{Cu}$ limitation. The $\mathrm{Crr} 1$ protein shares some similarity with the plant DNA-binding domain named squamosa-promoter- binding-protein family (SBP) and contains Zn fingers in its DNA-binding domain (Kropat et al. 2005). The Crr1-SBP domain specifically binds CuRE within 
$\mathrm{Cyt}_{6}$ and $\mathrm{CPX1}$ promoter regions. Other interesting feature is that Crr1-protein can work as a transcriptional activator or as a repressor, depending on the position of the CuRE (Moseley et al. 2002). The Arabidopsis genome contains 17 proteins with a well-conserved DNA binding domain, (SBP domain), which are denoted SPL proteins (squamosa protein-like (SPL) proteins), some of them involved in flower development (Birkenbihl et al. 2005).

$\mathrm{Cu}$-protein substitution by functionally equivalent $\mathrm{Fe}$ proteins under low $\mathrm{Cu}$ has been welldocumented in different organisms. In plants, the chloroplastic $\mathrm{Cu} / \mathrm{ZnSOD}$ (CSD2) is replaced by the FeSOD upon $\mathrm{Cu}$ limitation. Under this condition, chloroplastic FeSOD mRNA, its transcript product and the activity levels increased, while either chloroplastic or cytosolic $\mathrm{Cu} / \mathrm{ZnSOD}$ levels are undetectable (Abdel-Ghany et al. 2005b). This finding is accompanied by a decrease in the expression of the corresponding $\mathrm{Cu}$ chaperone $\mathrm{CCS}$. This coordinated regulation of nuclear encoded genes at transcriptional level is probably controlled by the optimal use of chloroplastic available $\mathrm{Cu}$ ions and suggest that stromal $\mathrm{Cu}$ levels maybe regulate nuclear expression through a still unknown signalling pathway. Recently, using transgenic moss plants (Barbula unguiculata L.) it was determined that GTAC motif is a negative cis-acting element of the $F e S O D$ in response to $\mathrm{Cu}$ (Nagae et al. 2008). These authors also found that a SBP-type transcription factor (PpSBP2) and its related protein bound to the GTAC motif repressed the expression of FeSOD. Additionally, evidence that miRNA mediates this regulation in A. thaliana has been shown (Yamasaki et al. 2007, AbdelGhany and Pilon, 2008). More recently, it was found that the DNA binding domain of SPL7, the SPL protein most similar to Crr1 (transcription factor in Chlamydomonas reinhardtii), interacts with GTAC cores of the miR398 promoter in vitro. SPL7 regulates the expression of FeSOD gene and it is involved in the switching between $\mathrm{Cu} / \mathrm{ZnSOD}$ and FeSOD under $\mathrm{Cu}$ deficiency (Yamasaki et al. 2009). Additionally, SPL7 also activates the expression of $m i R 397, m i R 408$ and $m i R 857$ in low $\mathrm{Cu}$ conditions yielding the degradation of a series of $\mathrm{Cu}$-proteins and leading to appropriate $\mathrm{Cu}$ 
redistribution. It has been found that SPL7 activates some $\mathrm{Cu}$ transporters and chaperones, so it could be a master regulatory factor involved in $\mathrm{Cu}$ homeostasis.

Several Arabidopsis genes increased expression in response to low $\mathrm{Cu}$ availability, i.e, COPT1, COPT2, ZIP2 transporters, FRO3 metal reductase, $\mathrm{CCH}$ chaperone and chloroplastic FeSOD (Himelblau et al. 1998; Sancenón et al. 2003; Wintz et al. 2003; Abdel-Ghany et al. 2005b; Mukherjee et al. 2006). The theoretical analysis of the COPT2 promoter sequence showed putative cis elements responsive to both low $\mathrm{Fe}$ and low $\mathrm{Cu}$, suggesting that this promoter can integrate signalling pathways of deficiencies in both metals.

\subsubsection{Responses to copper toxicity}

Toxic levels of $\mathrm{Cu}$ occurs naturally in some soils whereas others may contain high levels of $\mathrm{Cu}$ as a result of anthropogenic release of heavy metals into the environment through application of pig and poultry slurries rich in $\mathrm{Cu}$, fertilizers accumulation, fungicides, industrial and urban activities, metaliferous mining or metal processing, and waste disposal technologies (Kabata-Pendias and Pendias 2001; Pilon-Smits and Pilon 2002). Cu concentration in non-contaminated soils and natural waters is ca. $20-30 \mathrm{mg} \mathrm{kg}^{-1}$ and $2 \mu \mathrm{g} \mathrm{kg}^{-1}$, respectively but in contaminated soils and waters can reach levels one hundred times higher (Fernandes and Henriques 1991). Additionally, atmospheric heavy metal emission has also been identified as an important source of heavy metal contamination in plants (Friedland 1990; Salim et al. 1992). At concentrations above those required for optimal growth $\mathrm{Cu}$ can be toxic for most plants with the exception of a few plant species that can hyperaccumulate metals (i.e., Arabidopsis halleri L., Silene vulgaris (Moench) Garcke, Thalspi caerulescens L.). It is worth mentioning that this toxicity is dependent on plant species, the concentration of metal supplied, exposure time and soil properties. In sensitive plant species or ecotypes $\mathrm{Cu}$ was shown to inhibit growth and to interfere with important cellular processes such as photosynthesis and respiration (Marschner 1995; Prasad and Strzalka 1999, Yruela 2005). In the 
presence of high levels of $\mathrm{Cu}(3-100 \mu \mathrm{M})$ plants normally show reduced biomass (reduction of the root and shoot volume, stem size, leaf size), chlorotic symptoms, necrosis, and inhibition of shoot and root growth. A lower content of chlorophyll and alterations of chloroplast structure and thylakoid membrane composition have been found in leaves of spinach, rice, wheat (Triticum durum L. cvv. Adanello and Ofanto), bean (Phaseolus coccineus L. cv. Piekny) and oregano (Origanum vulgare L.) in such growth conditions (Baszynski et al. 1988; Lidon and Henriques 1991; 1993; Ciscato et al. 1997; Pätsikkä et al. 1998; Quartacci et al. 2000; Panou-Filotheou et al. 2001). Particularly, degradation of grana stacking and stroma lamellae, increase in the number and size of plastoglobuli, and appearance of intrathylakoidal inclusions were observed. It has been proposed that $\mathrm{Cu}$ interferes with the biosynthesis of the photosynthetic machinery modifying the pigment and protein composition of photosynthetic membranes (Lidon and Henriques 1991; Maksymiec et al. 1994). Pätsikka et al. (2002) attributed the reduction of chlorophyll content to a $\mathrm{Cu}$-induced $\mathrm{Fe}$ deficiency. The substitution of the central $\mathrm{Mg}$ ion of chlorophyll by $\mathrm{Cu}$ in vivo has also been proposed as a damage mechanism leading to inhibition of photosynthesis (Küpper et al. 2003; Küpper and Kroneck 2005). Besides, lipid peroxidations, decrease of lipid content and changes in fatty acid composition of thylakoid membranes were also shown (Sandmann and Böger 1980; Luna et al. 1994; Maksymiec et al. 1994). As a consequence of those modifications, an alteration of PSII membrane fluidity was found (Quartacci et al. 2000). On the other hand, the decrease of the photochemical activity caused by $\mathrm{Cu}$ is accompanied in vivo by an alteration of the structure and composition of the thylakoid membranes, which can influence the conformation and function of the photosystems (Baszynski et al. 1988, Ouzounidou et al. 1992, Lidon and Henriques 1993). Baszynski and Kruppa (1995) proposed that those processes induced by $\mathrm{Cu}$ could involve either the destruction of the oxygen-evolving complex polypeptide composition or the interaction with ions necessary for proper functioning of the complex as $\mathrm{Mn}, \mathrm{Ca}$ and $\mathrm{Cl}$.

Plant cell cultures have been widely used as suitable model system to analyse cell stress 
response and adaptation, among many other studies on plant physiology. Related studies on cell culture from mesophyll cells provided information on functional cell organization changes induced by excess $\mathrm{Cu}$ that can be extrapolated to leaf cells in plants. Soybean cell suspensions exposed to excess $\mathrm{Cu}(10 \mu \mathrm{M})$ maintained the general cell organization pattern of the non-treated soybean cultures but excess $\mathrm{Cu}$ exposure induced changes in specific subcellular structures. Smaller chloroplasts with rounded shape and more numerous, with a denser structured internal membranes, no starch granules within chloroplasts and larger cytoplasmic vacuole were observed (Bernal et al. 2006b, 2006c). Similarly, chloroplasts of seven-week-old of Arabidopsis thaliana plants exposed to $50 \mu \mathrm{M}$ Cu during 2-14 days showed rather circular than ellipsoidal shape (Wójcik and Tukiendorf 2003). Starch grains disappeared and plastoglobuli became larger in chloroplasts from leaves of oregano exposed to excess $\mathrm{Cu}\left(10-25 \mu \mathrm{M} \mathrm{g}^{-1}\right)$ (Panou-Filotheou et al. 2001). Roots and shoots also sense the phytotoxicity of $\mathrm{Cu}$. Roots of oregano plants exposed to $13-25.5 \mu \mathrm{M} \mathrm{g}^{-1} \mathrm{Cu}$ (PanouFitlotheou and Bosabalidis 2004) revealed a destroyed epidermis and a cortex of large cells with folded walls. Cortical cells exhibited a metamorphosis of the amyloplasts into leucoplasts. In root vascular cylinder, the diameter of the xylem vessels increased.

As mentioned previously, it is well known that transition metals like $\mathrm{Cu}$ catalyze the formation of hydroxyl radicals $\left(\mathrm{OH}^{*}\right)$ from the non-enzymatic chemical reaction between superoxide $\left(\mathrm{O}_{2}{ }^{\circ-}\right)$ and $\mathrm{H}_{2} \mathrm{O}_{2}$ (Haber-Weiss reaction) (Halliwell and Gutteridge, 1984). Hence, the presence of excess $\mathrm{Cu}$ can cause oxidative stress in plants and subsequently increase the antioxidant responses due to increased production of highly toxic oxygen free radicals. Accordingly, it was observed that excess $\mathrm{Cu}$ in plants led to oxidative stress inducing changes in the activity and content of some components of the antioxidative pathways (i.e., ascorbate peroxidase (APX), catalase, dehydroascorbate reductase (DHAR), guiacol peroxidase, glutathione reductase (GR), monodehydroascorbate reductase (MDHAR), superoxide dismutases (SODs)) (De Vos et al. 1992; 
Luna et al. 1994; Stohs and Bagchi 1995; Navari-Izzo et al. 1998; Gupta et al. 1999; Drazkiewicz et al. 2003; Wang et al. 2004; Lombardi and Sebastiani, 2005). The ascorbate-gluthatione cycle has been reported to be involved in response to excess $\mathrm{Cu}$ (Gupta et al. 1999; Drazkiewicz et al. 2003). The antioxidant responses have been observed in leaves and roots being either $\mathrm{Cu}$ concentration or time-dependent as well as plant specie or ecotype dependent.

The mechanism of $\mathrm{Cu}$ toxicity on photosynthetic electron transport has extensively also been studied in vitro, and it was found that PSII is the most sensitive site to $\mathrm{Cu}$ toxicity. Both the acceptor and the donor sides of PSII were suggested as the main targets of $\mathrm{Cu}$ toxic action. On the PSII reducing side, the $\mathrm{Q}_{B}$ binding site and the Pheo-Fe- $\mathrm{Q}_{\mathrm{A}}$ domain have been reported as the most sensitive sites for $\mathrm{Cu}$ toxicity (for review see Barón et al.1995; Yruela 2005). The interaction of Cu toxicity with photoinhibitory and recovery processes on PSII has been also investigated (Yruela et al. 1996, Pätsikkä et al. 1998) demonstrating that Cu enhances the adverse effects of light. Considering that $\mathrm{Cu}$ is an efficient catalyst in the formation of reactive oxygen species (ROS), it was suggested that the increased $\mathrm{Cu}$ toxicity by light during photoinhibition is due to production of hydroxyl radicals (Yruela et al. 1996). A different proposal was given by Pätsikkä et al. (2002) suggesting that the reduced chlorophyll content observed in plant leaves grown in the presence of high $\mathrm{Cu}$ concentrations made leaves more susceptible to photoinhibition as a consequence of a $\mathrm{Cu}$-induced $\mathrm{Fe}$ deficiency.

Susceptibility to excess $\mathrm{Cu}$ varies with plant species and ecotypes. For instance, alfalfa and barley are highly tolerant to excess $\mathrm{Cu}$, but rice (Oryza sativa) and potato are less tolerant (Jones 1998). To better understanding such differences and how plants adapt to metal stress it is important to know how excess $\mathrm{Cu}$ affects gene expression.

DNA microarrays are powerful tools for providing an overview of gene expression under environmental conditions and in particular under $\mathrm{Cu}$ stress. Recently, several works have been done with this purpose. Weber et al. (2006) examined transcriptome changes upon $\mathrm{Cd}^{2+}$ and $\mathrm{Cu}^{2+}$ exposure 
in roots of the Cd-hypertolerant metallophyte $A$. halleri. They did not find any evidence for $\mathrm{Cu}^{2+}$ specific responses. The overlap between $A$. thaliana and $A$. halleri was extensive. Most of the genes responsive to $\mathrm{Cu}^{2+}$ in $A$. halleri were also found in the $A$. thaliana list. With very few exceptions, the genes of the 'Arabidopsis $\mathrm{Cu}^{2+}$ core response' were strongly responsive to many other abiotic stresses such as ozone, salt, cold and osmotic shock. This is likely due to the fact that excess $\mathrm{Cu}^{2+}$ triggers the massive generation of reactive oxygen species, which is a consequence of most other biotic and abiotic stresses. Keinämen et al. (2007) identified genes that are up-regulated by $\mathrm{Cu}$ exposure in a Cu-tolerant birch (Betula pendula Roth.) clone. More recently, Sudo et al. (2008) examined gene expression in response to excess $\mathrm{Cu}$ in rice leaves. Microarray analysis revealed that $\mathrm{Cu}$ treatment particularly affects genes involved in defence, abiotic stresses, photosynthesis and transport. A large proportion of general and defence stress response genes are up-regulated under excess $\mathrm{Cu}$ conditions whereas photosynthesis and transport-related genes are down-regulated. The results suggest that the defence response has an essential role in the stress response to excess $\mathrm{Cu}$. The defence-related genes involved in phytoalexin and lignin biosynthesis were the most sensitive to $\mathrm{Cu}$. Defence-related genes could be effective targets for increasing $\mathrm{Cu}$ tolerance. Thus, the role of $\mathrm{Cu}$ as an antifungal agent may act in part by inducing defence-response genes, as well as by inhibiting the pathogen (Sudo et al. 2008). Additionally, plant management of abiotic and pathogen stresses had overlapping components, likely including signal transduction.

Proteomic approach has been also used to investigate the plant response to excess $\mathrm{Cu}$. Bona et al. (2007) analyzed the root proteome of Cannabis sativa L., an annual herb with capability to absorb and accumulate heavy metals in roots and shoots, exposed to $150 \mu \mathrm{g} \mathrm{g}^{-1} \mathrm{Cu}^{2+}$. Cu upregulated several proteins being the aldo/keto reductase the most up-regulated protein, which is a NAD(P)H-dependent enzyme widely distributed from mammals to insects, fungi and yeast. Its increase was associated to its involvement in detoxification process. Besides, actin, an important component of plant cytoskeleton and microfilaments, formate deshydrogenase (FHD), a 
mitochondrial NAD-dependent enzyme which catalyzes the oxidation of formate into $\mathrm{CO}_{2}$ mantaining a reduced environment, and the $40 \mathrm{~S}$ ribosomal protein involved in protein synthesis machinery, were increased. In Cannabis sativa L., $\mathrm{Cu}$ also down-regulated proteins such as thioredoxin peroxidase, enolase, glutaredoxin and cyclophilin (Bona et al. 2007).

\subsubsection{Tolerance mechanisms to copper toxicity}

In order to avoid metal toxicity all plants possess basal tolerance mechanisms, which appear to be involved primarily in avoiding the accumulation of toxic concentrations at sensitive sites within the cell preventing the damaging effects rather than developing proteins that can resist the heavy metal effects. The potential cellular mechanisms involved in tolerance include those by: $i$ ) reducing metaluptake through mycorrhiza action or extracellular exudates; ii) immobilizating excess of $\mathrm{Cu}$ in the root and thus excluding the metal from the shoot; $\mathrm{iii}$ ) stimulating the efflux pumping metal at the plasma membrane; iv) chelation of metals by phytochelatins, metallothioneins, organic acids or heat shock proteins; v) compartmentation of metals in the vacuole (Hall 2002; Krämer and Clemens 2006). There is little evidence that tolerant species or ecotypes show an enhanced oxidative defence; tolerant plants show rather enhanced avoidance and homeostatic mechanisms to prevent the stress (De Vos et al. 1991; Dietz et al. 1999).

Intraspecific and interspecific differences in sensitivity to $\mathrm{Cu}$ do occur between different plant species. On the other hand, with regard to mechanisms allowing $\mathrm{Cu}$ tolerance, a question of interest is whether this tolerance is constitutive in each species or depends on previous long-term exposure to metal. Van Thichelen et al. (2001) showed that some mycorrhizal species protect Pinus sylvestris $\mathrm{L}$. against $\mathrm{Cu}$ toxicity extracelullarly, although the amount of $\mathrm{Cu}$ retained by different fungi varies considerably. The mechanisms employed by the fungi are probably by binding to extracellular materials. Organic acids (citrate, malate, oxalate), carbohydrates, proteins or peptides enriched in cysteine or hystidil groups excreted by plants can facilitate metal uptake, but these 
molecules can also inhibit metal acquisition by forming a complex with it outside the root that is not taken up. The importance of these mechanisms may vary in accordance with the concentration of metal supplied, plant specie or variety involved and the exposure time.

Dark deposits attached at the outer surface of the cell wall containing high level of $\mathrm{Cu}$ have been observed in plants grown under metal stress conditions (Vitória et al. 2006). Similar deposits were observed in $\mathrm{Cu}$-stressed soybean cell suspensions that were accompanied by the accumulation of higher levels of citrate and malate (Bernal et al. 2006c). Similar levels of citrate and malate in copper tolerant Nicotiana plumbaginifolia L. cells were reported (Kishinami and Widholm 1987). Citrate appears to be responsible for $\mathrm{Cu}$ tolerance in A. thaliana (Murphy et al. 1999). Citrate synthesis was preferentially stimulated during the first time of $\mathrm{Cu}$ exposure in soybean cell suspensions, being one of the fastest responses to $\mathrm{Cu}$ exposure (Bernal et al. 2006c). Two organic acids exudation responses differing in time have been observed in roots of aluminium (Al) resistant plants (for review see Mariano et al. 2005). In the former response organic acids release is rapidly activated after $\mathrm{Al}$ exposure and the rate of release remains constant with time. In this case it has been suggested that $\mathrm{Al}$ activates a constitutive mechanism of organic acids transport in the plasma membrane and the activation of genes is not necessary. Al can activate anion channels, which have been proposed as the mediators of organic acids transport across the cell membranes. In the second one there is a delay in the organic acids release after the addition of $\mathrm{Al}$ and this release increases with time. In this case the activation of genes related to the metabolism and membrane transport of organic acids might be required.

Once inside the root cells, metals are translocated by membrane metal transporters and metalbinding proteins to their final destination. This process involves specific proteins (i.e., metallothioneins, metallochaperones or low-molecular-weight metal chelators) that must maintain a fine balance between having enough essential metals available for metabolic functions and at the same time avoiding deficiency or toxicity. Excess metals are stored in a location where the metal can 
do the least harm to cellular processes. This involves storage in special cellular compartments such as the vacuole. Sequestration may also be in the apoplast, or in specialized cells such as epidermal cells and trichomes.

Despite the widespread occurrence of metallothioneins (MTs) and the relatively high level of RNA expression of many MT genes, their function in plants remain poorly understood. Expression of some MT genes is induced by $\mathrm{Cu}: i$ ) the level of expression of 2-type MT gene correlate closely with $\mathrm{Cu}$ tolerance in a group of $A$. thaliana ecotypes (Murphy and Taiz 1995); ii) expression of 2type MT is elevated in a $\mathrm{Cu}$-sensitive mutant that accumulates $\mathrm{Cu}$ (van Vliet et al. 1995); iii) $\mathrm{Cu}$ tolerance in the metallophyte plants Silene vulgaris (Moench) Garcke and Silene paradoxa L. was associated with increased levels of a 2b-type MT (van Hoof et al. 2001; Mengoni et al 2003); iv) the yeast MT CUP1 gene introduced into tobacco plants contributed to $\mathrm{Cu}$ metal phytoextraction (Thomas et al. 2003). However, the involvement of MTs in $\mathrm{Cu}$ detoxification in plant has not been conclusively demonstrated. The divergence of plant MT protein sequences and the complex expression patterns of MT genes suggest that the functions of MTs may not be limited to $\mathrm{Cu}$ detoxification. Recently Guo et al. (2008) have reported direct evidence for functional contributions of MTs to metal homeostasis in plants.

The role of phytochelatins (PCs) in $\mathrm{Cu}$ detoxification has not been shown. $\mathrm{Cu}$ is a strong activator of PC biosynthesis but PC-deficient mutants show relatively little sensitivity to $\mathrm{Cu}$. Since PCs can form complexes with $\mathrm{Cu}$ it could be possible that $\mathrm{PC}-\mathrm{Cu}$ complexes are not sequestered in the vacuole (Cobbet and Goldsbrough 2002).

$\mathrm{P}_{1 \mathrm{~B}}$-type $\mathrm{Cu}$ transporting ATPases are thought to be important not only in obtaining sufficient amounts of $\mathrm{Cu}$ ions for essential cell functions but also in preventing accumulations of these ions to toxic levels. On the other hand, $\mathrm{Cu}$ ions are chelated by specific chaperones and delivered to $\mathrm{Cu}$ pumps for transport into organelles or directly to cytosolic $\mathrm{Cu}$ dependent proteins. Thus, both $\mathrm{Cu}$ chelation and $\mathrm{Cu}$ pumping activity likely are not only required for $\mathrm{Cu}$-uptake but also for 
detoxification processes. Thus, these transporters and chaperones could be involved in the overall strategy of $\mathrm{Cu}$ tolerance. A possible role of metal transporters and chaperones in phytoremediation (defined as the use of green plants to remove pollutants from the environment or to render them harmless) has been proposed. Putative candidates to improve $\mathrm{Cu}$ phytoremediation include root $\mathrm{Cu}$ reductases and transporters, NA synthases and two $\mathrm{Cu}$ detoxification proteins: P-type ATPases and MTs (Puig et al. 2007). Concerning P-type ATPases, the Cu-tolerant plant Silene vulgaris (Moench) Garcke displays enhanced ATP-dependent $\mathrm{Cu}$ efflux across the root cell plasma membrane (Van Hoof et al. 2001). Furthermore, the inactivation of the ActP gene, which encodes a P-type ATPase, causes $\mathrm{Cu}$ hypersensitivity in Rhizobium legominosarum and Sinorhizobium meliloti (Reeve et al. 2002). In A. thaliana, AtHMA5 has been proposed as a candidate for overexpression to improve $\mathrm{Cu}$ detoxification (Andrés-Colás et al. 2006). More recently, Gao et al. (2009) have suggested the possible role of acyl-CoA-binding protein 2, ACBP2, and farnesylated protein AtFP6 in mediating $\mathrm{Cu}, \mathrm{Cd}$ and $\mathrm{Pb}$ transport in $A$. thaliana roots. A. thaliana plants overexpressing ACBP2 or AtFP6 were more tolerant to $\mathrm{Cd}$ than wild-type plants suggesting a similar role in $\mathrm{Cu}$ tolerance.

As mentioned above differences in sensitivity to $\mathrm{Cu}$ have been found among plant varieties. In order to understand the origin of such variations quantitative trait locus (QTL) analyses has been used to investigate the interaction between molecular mechanisms of $\mathrm{Cu}$ tolerance and phenotypic differences. A QTL study in Arabidopsis identified that $\mathrm{Cu}$ sensitivity was correlated with a major QTL on chromosome 1 (Kobayashi et al. 2008). This QTL1 regulates the Cu translocation capacity and involves the $\mathrm{Cu}^{+}$-transporting $\mathrm{P}_{1 \mathrm{~B}}$-type ATPase $A t \mathrm{HMA5}$. The results revealed that amino acid polymorphisms in strictly conserved motifs of $A t \mathrm{HMA} 5$ are involved in $\mathrm{Cu}$ tolerance of the roots and explain $\mathrm{Cu}$ tolerance variations in Arabidopsis. The same mechanism (i.e. substitution of amino acids in conserved domains) was identified as a cause of dysfunctional $\mathrm{Cu}$ homeostasis in human Menkes and Wilson diseases. This may support the importance of HMA5 in Cu tolerance and therefore the importance of $\mathrm{Cu}$ homeostasis in $\mathrm{Cu}$ tolerance. Similar mechanisms may contribute to 
natural variation in plant tolerance to $\mathrm{Cu}$, especially for root growth, but further studies are necessary to clarified that.

\section{INTERACTIONS BETWEEN COPPER AND OTHER ELEMENTS}

In general transition metal ions are distinguished by their different chemical properties, i.e. redox potential, coordination geometry, charge and thermodynamic and kinetic properties of ligand exchange. Accordingly, in a given metalloenzyme, a specific metal ion is used for a specific function. However, according to the Irving-Williams series $\left(\mathrm{Zn}^{2+}<\mathrm{Cu}^{+}>\mathrm{Cu}^{2+}>\mathrm{Ni}^{2+}>\mathrm{Co}^{2+}>\mathrm{Fe}^{2+}\right.$ $>\mathrm{Mn}^{2+}>\mathrm{Mg}^{2+}>\mathrm{Ca}^{2+}$ ) metal ions can bind to organic ligands in a metal-binding site of a metalloprotein, metal-chaperone or metal transporter with different affinities (Fraústo da Silva and Williams 2001). Thus, although binding affinity for a metal ion is also determined by other secondary factors such as the size of metal binding-site cavity in a protein, the geometry of ligand atoms and other characteristic, normally each metal ion can be replaced by other metal ion downstream in the Irving-Williams series. A further implication of the chemical principles illustrated by the Irving-Williams series is that metal homeostasis of one transition metal should generally not be considered alone, but always in the context of all cations and their respective concentrations. Cations chemically similar to other can enter into plants by competing with uptake pathways for macronutrients and micronutrients metal ions. Consequently in metal-pollutes areas toxic metal ions can enter into most plants since metal homeostasis network are not equipped to avoid the entry of non-essential metal transitions at high concentration. Therefore, one major mechanism of toxic action of all transition metal is the efficient competition of metal ions for specific binding sites, consequently, displacements of essential metal ions from their binding sites can occur. For instance, it has been shown that the central ion $\mathrm{Mg}^{2+}$ in chlorophyll was substituted by $\mathrm{Cu}$ and other toxic metals under metal excess conditions resulting in an impairment of the correct function of the 
chlorophyll-complexes (i.e. light harvesting antenna complex) because metal-substituted chlorophylls are not suitable for photosynthesis (Küpper and Kroneck 2005).

In plants relatively little is known about $\mathrm{Cu}$ transport into and within cells showing a dependence on $\mathrm{Cu}$ for $\mathrm{Fe}, \mathrm{Zn}, \mathrm{Mn}$ and other element assimilation. Schmidt (1999) reported that $\mathrm{Cu}$ and Fe compete in ion-uptake. Pätsikkä et al. (2002) observed that excess $\mathrm{Cu}$ in hydroponic medium induces a Fe-deficiency in bean plants. Chen et al. (2004) observed that Fe-deficiency induces $\mathrm{Cu}$ accumulation in Commelina communis L. plants. Furthermore, Rombolà et al. (2005) found that Fedeficiency increases the $\mathrm{Cu}$ content and decreases the $\mathrm{Zn}$ content in leaf blades of sugar beet grown hydroponically. $\mathrm{Cu}$ and $\mathrm{Fe}$ antagonism often occurs in plants grown under $\mathrm{Cu}$ toxicity (Foy et al. 1978; Wallace and Cha, 1989; Lombardi and Sebastiani 2005). Nevertheless, opposite scenario has been also observed in oregano (Panou-Filotheou et al. 2001), rice seedlings (Kitagishi and Yamane 1981) and wheat (Triticum aestivum L. cv Vergina) (Lanaras et al. 1993) plants exposed to Cu toxicity in soil. An increasing concentration of soil $\mathrm{Cu}$ resulted in a parallel increase in leaf $\mathrm{Cu}$ content with no reduction in the leaf $\mathrm{Fe}$ and $\mathrm{Mg}$. These apparently contradictory results may be explained by different tolerance strategies adopted by different plants.

Other organisms such as mammal cells, yeast or certain algae do not appear to manifest a competition showing a dependence on $\mathrm{Cu}$ for Fe assimilation (Franklin et al. 2002). A Cu dependent Fe assimilation pathway has been found in the unicellular green alga Chlamydomonas reinhardtii (La Fontaine et al. 2002). Additionally, an antagonist interaction between $\mathrm{Cu}$ and $\mathrm{Zn}$ was observed in this alga (Herbik et al. 2002). Similar feature has been observed in some plants. Soil Cu affected negatively the accumulation of $\mathrm{Zn}$ in roots of oregano (Panou-Filotheou and Bosabalidis 2004). More recently, Bernal et al. (2007a) demonstrated that $\mathrm{Cu}$ interacts differently with Fe and $\mathrm{Zn}$ depending on the pathway through excess $\mathrm{Cu}$ is supplied. Thus, soybean plants treated with excess $\mathrm{Cu}$ through leaves behave differently than plants treated by supplementing the growth medium with excess $\mathrm{Cu}$. Soybean plants showed no antagonist interaction between $\mathrm{Cu}$ - and $\mathrm{Fe}$-uptake when 
excess $\mathrm{Cu}$ was supplied through leaves but $\mathrm{Cu}$ compete with Fe-uptake in plants grown with excess $\mathrm{Cu}$ in the hydroponic medium. Concerning Zn-uptake soybean plants exhibited Zn content decrease upon $\mathrm{Cu}$ treatment of leaves whereas the opposite was observed upon $\mathrm{Cu}$ treatment through roots. Interestingly, plants with $\mathrm{Cu}$-treated leaves behaved similarly as soybean cell suspensions grown in the presence of excess $\mathrm{Cu}$ (Bernal et al. 2006b, 2006c). The different plant response observed upon these two $\mathrm{Cu}$-treatments might be explained assuming different $\mathrm{Cu}$-uptake strategies in leaf and root cells.

\section{PROSPECTS}

This review shows that progress in understanding $\mathrm{Cu}$ homeostasis in plants has been noticeable in last decade, but there are still unclear aspects or little investigated. For instance, several families of genes involved in regulation of $\mathrm{Cu}$ homeostasis have been identified and their expression analyzed under either deficiency or excess $\mathrm{Cu}$ conditions, but little is known about the structure and functional mechanisms of proteins generated by those genes. Some of these proteins are inserted in the membranes of cells and organelles, and it is true that structural studies on membrane proteins are difficult but further biochemical and structural studies including molecular interactions and molecular recognition of proteins involved in $\mathrm{Cu}$ homeostasis should be necessary to know the molecular basis of $\mathrm{Cu}$ trafficking and transport.

On the other hand, most of molecular studies are focused in intracellular homeostasis being the information on $\mathrm{Cu}$ distribution and remobilization in xylem and phloem saps as well as $\mathrm{Cu}$ xylem-to-phloem exchange less available. Furthermore, researchers should pay more attention to metal interactions by their relevant implications in $\mathrm{Cu}$ distribution and remobilization within the plant.

Other interesting aspect to further explore is the putative significant role of $\mathrm{Cu}$ chaperones and transporters in $\mathrm{Cu}$ tolerance. Recently, it has been point out the role of AtHMA5 transporter, 
involved in $\mathrm{Cu}$ transport in roots, as important element in $\mathrm{Cu}$ tolerance mechanisms but it is unknown if other proteins involved in $\mathrm{Cu}$ transport and trafficking are also candidates. Moreover, variations in $\mathrm{Cu}$ tolerance exist among plant varieties however the involvement of specific genes related with $\mathrm{Cu}$ homeostasis in determining such variations have been little investigated. Studies of natural variations based on quantitative trait locus (QTL) analysis have provided a useful approach to understand the mechanisms of variation in target traits such as freezing tolerance, salinity tolerance, growth and flowering among others. Recently, this approach has been applied in Arabidopsis to identify critical genes regulating variations in $\mathrm{Cu}$ tolerance (Kobayashi et al. 2008). The results revealed that amino acid polymorphisms in certain genes involved in $\mathrm{Cu}$ transport can be responsible of such variations. These studies suggest that the combination of association mapping analysis and the biochemical approach could be useful to identify key genes regulating variations related to $\mathrm{Cu}$ tolerance or sensitivity among genotypes and varieties. An interesting question for future research is if the same mechanisms found in Arabidopsis can explain variations in $\mathrm{Cu}$ tolerance of other crop species. The understanding of such mechanisms may be used in molecular breeding programmes (i.e. marker-assisted selection).

\section{CONCLUSION}

In summary, our knowledge of $\mathrm{Cu}$ and heavy metals homeostasis is still rudimentary in some cases. A comprehensive understanding of $\mathrm{Cu}$ transport and trafficking across plant membranes and distribution and remobilization through xylem and phloem saps, at the molecular level, including metal interactions as well as variations in $\mathrm{Cu}$ tolerance and sensitivity in plants will be essential for developing schemes to genetically engineer plants that accumulate specific metals, either for use in phytoremediation or to improve human nutrition. 


\section{AKNOWLEDGEMENTS}

This work was supported by Ministry of Education and Science (BFU 2005-07422-C02-01) and the Aragón Govermment (GC E33 DGA programme).

\section{REFERENCES}

Abdel-Ghany SE, Burkhead JL, Gogolin KA, Andrés-Colás N, Bodecker JR, Puig S, Peñarrubia L, Pilon M (2005a) AtCCS is a functional homolog of the yeast copper chaperone Ccs1/Lys7. FEBS Letters 579, 2307-2312

Abdel-Ghany SE, Müller-Moulé P, Niyogi KK, Pilon M, Shikanai T (2005b) Two P-type ATPases are required for copper delivery in Arabidopsis thaliana chloroplasts. Plant Cell 17, 1-19

Abdel-Ghany SE, Pilon M (2008) MicroRNA-mediated systemic down-regulation of copper protein expression in response to low copper availability in Arabidopsis. Journal of Biological Chemistry 283, 15932-15945

Aller SG, Eng ET, De Feo CJ, Unger VM (2004) Eukaryotic CTR copper uptake transporters require two faces of the third transmembrane domain for helix packing, oligomerization, and function. Journal of Biological Chemistry 279, 53435-53441

Aller SG, Unger VM (2006) Projection structure of the human copper transporter CTR1 at 6-Å resolution reveals a compact trimer with a novel channel-like architecture. Proceedings of the National Academy of Science, USA 103, 3627-3632

Alonso JM, Hirayama T, Roamn G, Nourizadeh S, Ecker JR (1999) EIN2, a bifunctional transducer of ethylene and stress response in Arabidopsis. Science 284, 2148-2152

Andrés-Colás N, Sancenón V, Rodríguez-Navarro S, Mayo S, Thiele DJ, Ecker JR, Puig S, Peñarrubia L (2006) The Arabidopsis heavy metal P-type ATPasa HMA5 interacts with metallochaperones and functions in copper detoxification of roots. Plant Journal 45, 225-236 Argüello JM (2003) Identification of ion-selectivity determinants in heavy-metal transport $\mathrm{P}_{1 \mathrm{~B}}$-type 
ATPases. Journal of Membrane Biology 195, 93-108

Argüello JM, Eren E, González-Guerrero M (2007) The structure and function of heavy metal transport P1B-ATPases. Biometals 20, 233-248

Argüello JM, González-Guerrero M (2008) $\mathrm{Cu}^{+}$-ATPases brake system. Structure 16:833-834 Axelsen KB, Palmgren MG (2001) Inventory of the superfamily of P-type ion pumps in Arabidopsis. Plant Physiology 126, 696-706

Baker DE, Senef JP (1995) Copper. In: Alloway BJ (ed) Heavy metals in soils. Blackie Academic and Professional, London, s, pp 179-205

Balandin T and Castresana C (2002) AtCOX17, an Arabidopsis homolog of the yeast copper chaperone COX17. Plant Physiology 129, 1852-1857

Barón M, López-Gorgé J, Lachica M, Sadmann G (1992) Changes in carotenoids and fatty acids in photosysyem II of Cu-deficient pea plants. Physiologia Plantarum 84, 1-5

Barón M, Arellano JB, López-Gorgé J (1995) Copper and photosystem II: A controversial relationship. Physiologia Plantarum 94, 174-180

Barr R, Crane FL (1976) Organization of electron transport in photosystem II of spinach chloroplasts according to chelator inhibition sites. Plant Physiology 57, 450-453

Baszynski T, Ruszkowska M, Król M, Tukendorf A, Wolinska D (1978) The effect of copper deficiency on the photosynthetic apparatus of higher plants. Zeitschrift für Pflanzenphysiologie 89, 207-216

Baszynski T, Tukendorf A, Ruszkowska M, Skórzynska E, Maksymiec W (1988) Characteristics of the photosynthetic apparatus of copper non-tolerant spinach exposed to excess copper. Journal of Plant Physiology 132, 708-713

Baszynski T, Krupa Z (1995) Some aspects of heavy metal toxicity towards photosynthetic apparatus-direct an indirect effects on light and dark reactions. Acta Physiologiae Plantarum 17, $177-191$ 
Baxter I, Tchieu J, Sussman MR, Boutry M, Palmgren MG, Gribskov M, Harper JF, Axelsen KB (2003) Genomic comparison of P-type ATPase ion pumps in Arabidopsis and rice. Plant Physiology 132, 618-628

Belouchi A, Cellier M, Kwan T, Saini HS, Leroux G, Gros P (1995) The macrophage-specific membrane protein Nramp controlling natural resistance to infections in mice has homologues expressed in the root system of plants. Plant Molecular Biology 29, 1181-1196

Belouchi A, Kwan T, Gros P (1997) Cloning and characterization of the OsNramp family from Oryza sativa, a new family of membrane proteins possibly implicated in the transport of metal ions. Plant Molecular Biology 33, 1085-1092

Bernal M (2006a) Mecanismos de tolerancia al exceso de cobre en suspensiones celulares de soja. Caracterización del transportador de cobre HMA8 Ph D. Thesis Estación Experimental de Aula Dei, Consejo Superior de Investigaciones Científicas (CSIC), Zaragoza, Spain. Available at http://hdl.handle.net/10261/2873.

Bernal M, Ramiro MV, Cases R, Picorel R, Yruela I (2006b). Excess copper effect on growth, chloroplast ultrastructure, oxygen-evolution activity and chlorophyll fluorescence in Glycine max cell suspensions. Physiologia Plantarum 127, 312-325

Bernal M, Sánchez-Testillano P, Risueño MC, Yruela I (2006c) Excess copper induces structural changes in cultured photosynthetic soybean cells. Functional Plant Biology 33, 1001-1012

Bernal M, Cases R, Picorel R, Yruela I (2007a) Foliar and root Cu supply affect differently Fe and Zn uptake and photosynthetic activity in soybean plants. Environmental and Experimental Botany 60, 145-150

Bernal M, Sánchez-Testillano PS, Alfonso M, Risueño MC, Picorel R, Yruela I (2007b) Identification and subcellular localization of the soybean copper $\mathrm{P}_{1 \mathrm{~B}}$-ATPase GmHMA8 transporter. Journal of Structural Biology 158, 46-58

Bertrand M, Poirier I (2005) Photosynthetic organisms and excess of metals. Photosynthetica 43, 
345-353

Birkenbihl RP, Jach G, Saedler H, Huijser P (2005) Functional dissection of the plant-specific SBPdomain: overlap of the DNA-binding and nuclear localization domains. Journal of Molecular Biology 352, 585-596

Bona E, Marsano F, Cavaletto M, Berta G (2007) Proteomic characterization of copper stress response in Cannabis sativa roots. Proteomics 7, 1121-1130

Bueno P, Varela J, Giménez-Gallego G, del Rio LA (1995) Peroxisomal copper, zinc superoxide dismutase: characterization of the isoenzyme from watermelon cotyledons. Plant Physiology 108, 1151-1160

Brun LA, Maillet J, Hinsinger P, Pépin M (2001) Evaluation of copper availability to plants in copper-contaminated vineyard soils. Environmental Pollution 111, 293-302

Burda K, Kruk J, Strzałka K, Schimd GH (2002) Stimulation of oxygen evolution in photosystem II by copper. Zeitschrift für Naturforschung. Section C-A Journal of Biosciences 57c, 853-857

Burkhead JL, Abdel-Ghany SE, Morrill JM, Pilon-Smits E, Pilon M (2003) The Arabidopsis thaliana CUTA gene encodes an evolutionary conserved copper binding chloroplast protein. Plant Journal 34, 856-867

Carrillo-González R, Simünek J, Sauvé S, Adriano D (2006) Mechanisms and pathways of trace element mobility in soils. Advanced Agronomy 91, 113-180

Chaignon V, Di Malta D, Hinsinger P (2002) Fe-deficiency increases Cu acquisition by wheat cropped in a Cu-contaminated vineyard soil. New Phytologist 154, 121-130

Chaignon V, Sanchez-Neira I, Hermann P, Jaillard B, Hinsinger P (2003) Copper bioavailability and extractability as related to chemical properties of contaminated soils from a vinegrowing area. Environmental Pollution 123, 229-238

Chen-Chou W, Rice WJ, Stokes DL (2008) Structure of a Copper Pump Suggests a Regulatory Role for Its Metal-Binding Domain. Structure 16, 976-985 
Chen YF, Randlett MD, Findell JL, Schaller GE (2002) Localization of the ethylene receptor ETR1 to the endoplasmic reticulum of Arabidopsis. Journal of Biological Chemistry 277, 1986119866

Chen Y, Shi J, Tian G, Zheng S, Lin Q (2004) Fe deficiency induces Cu uptake and accumulation in Commelina communis. Plant Science 166, 1371-1377

Chiou T (2007) The role of microRNAs in sensing nutrient stress. Plant Cell and Environment 30 , $323-332$

Chu CC, Lee WC, Guo WY, Pan SM, Chen LJ, Li HM, Jinn TL (2005) A copper chaperone for superoxide dismutase that confers three types of copper/zinc superoxide dismutase activity in Arabidopsis. Plant Physiology 139, 425-436

Ciscato M, Valcke R, van Loven K, Clijsters H, Navari-Izzo F (1997) Effects of in vivo copper treatment on the photosynthetic apparatus of two Triticum durum cultivars with different stress sensitivity. Physiologia Plantarum 100, 901-908

Cobbet C, Goldsbrough P (2002) Phytochelatins and metallothioneins: roles in heavy metal detoxification and homeostasis. Annual Review of Plant Biology 53, 159-182

Cobbet CS, Hussain D, Haydon MJ (2003) Structural and functional relationships between type $1_{B}$ heavy metal transporting P-type ATPases in Arabidopsis. New Phytologist 159, 315-321

Colangelo EP, Guerinot ML (2006) Put metal to petal: metal uptake and transport throughout plants. Current Opinion of Plant Biology 9, 322-330

Company P, González-Bosch C (2003) Identification of a copper chaperone from tomato fruits infected with Botrytis cinerea by differential display. Biochemical and Biophysical Research Communication 304, 825-830

Cornu JY, Staunton S, Hinsinger P (2007) Copper concentration in plants and in the rizhosphere as influenced by the iron status of tomato (Lycopersicon esculentum L.). Plant and Soil 292, 6377 
Curie C, Alonso JM, Le Jean M, Ecker JR, Briat JF (2000) Involvement of Nramp 1 from Arabidopsis thaliana in iron transport. Biochemical Journal 347, 749-755

Curie C, Panaviene Z, Loulergue C, Dellaporta SL, Briat JF, Walker EL (2001) Maize yellow stripe1 encodes a membrane protein directly involved in Fe(III) uptake. Nature 409, 346-349

Curie C, Cassin G, Couch D, Divol F, Higuchi K, Le Jean M, Misson J, Schikora A, Czernic P, Mari S (2009) Metal movement within the plant: contribution of nicotianamine and yellow stripe 1-like transporters. Annals of Botany 103, 1-11

De Vos CHR, Schat H, De Waal MAM, Voojis R, Ernst WHO (1991) Increased resistance to copper-induced damage of the root cell plasmalemma in copper tolerant Silene cucubalus. Physiologia Plantarum 82, 523-528

De Vos CHR, Vonk MJ, Voojis R, Schat H (1992) Glutathione depletion due to copper-induced phytochelatin synthesis causes oxidative stress in Silene cucubalus. Plant Physiology 98, $853-858$

DiDonato RJ, Jr, Roberts LA, Sanderson T, Eisley RB, Walker EL (2004) Arabidopsis yellow stripelike2 (YSL2): a metal-regulated gene encoding a plasma membrane transporter of nicotianamine-metal complexes. Plant Journal 39, 403-414

Dietz K-J, Baier M, Krämer U (1999) Free radicals and reactive oxygen species as mediators of heavy metal toxicity in plants. In: Prasad MNV, Hagemeyer J (eds) Heavy metal stress in plants: from molecules to ecosystems. Springer-Verlag, Berlin, pp 73-97

Drazkiewicz M, Skórzynska-Polit E, Krupa Z (2003) Response of the ascorbate-glutathione cycle to excess copper in Arabidopsis thaliana (L.). Plant Science 164, 195-202

Droppa M, Masojidek J, Rózsa Z, Wolak A, Horváth LI, Farkas T, Horváth G (1987) Characteristics of $\mathrm{Cu}$ deficiency-induced inhibition of photosynthetic electron transport in spinach chloroplasts. Biochimica et Biophysica Acta 891, 75-84

Eisses JF, Kaplan JH (2002) Molecular characterization of hCTR1, the human copper uptake protein 
Journal of Biological Chemistry 277, 29612-29171

Eriksson M, Moseley JL, Tottey S, Del Campo JA, Quinn J, Kim Y, Merchant S (2004) Genetic dissection of nutritional copper signaling in Chlamydomonas distinguishes regulatory and target genes. Genetics 168, 795-807

Fernandes JC, Henriques FS (1991) Biochemical, physiological and structural effects of excess copper on plants. Botanical Review 57, 246-273

Fox TC, Guerinot ML (1998) Molecular biology of cation transport in plants. Annual Review of Plant Physiology 49, 669-696

Foy CD, Chaney RL, White MC (1978) The physiology of metal toxicity in plants. Annual Review of Plant Physiology 29, 511-566

Franklin N, Stauber JL, Lim RP, Petocz P (2002). Toxicity of metal mixtures to a tropical freshwater alga (Chlorella sp). The effect of interactions between copper, cadmium and zinc on metal cell binding and uptake. Environmental Toxicology and Chemistry 21, 2412-2422

Fraústo da Silva JJR, Williams RJP (2001) The Biological Chemistry of the Elements, 2 nd edn. Clarenton Press, Oxford, UK

Friedland AJ (1990) The movement of metals through soils and ecosystems. In: Shaw AJ (ed) Heavy metal tolerance in plants: evolutionary aspects, CRC Press, Inc, Boca Raton, Florida, pp 7-37

Gao W, Xiao S, Li H-Y, Tsao S-W, Chye M-L (2009) Arabdopsis thaliana acyl-CoA-binding protein ACBP2 interacts with heavy-metal-binding farnesylated protein AtFP6. New Phytologist 181, 89-102

Gendre D, Czernic P, Conéjéro G, Pianelli Katia; Briat J-F, Lebrun M, Mari S (2007) TcYSL3, a member of the YSL gene family from the hyper-accumulator Thlaspi caerulescens, encodes a nicotianamine-Ni/Fe transporter Plant Journal 49, 1-15

González-Guerrero M, Argüello JM (2008) Mechanism of $\mathrm{Cu}^{+}$-transporting ATPases: soluble $\mathrm{Cu}^{+}$ chaperones directly transfer $\mathrm{Cu}^{+}$to transmembrane transport sites. Proceedings of the 
National Academy of Science, USA 105, 5992-5997

Gratão PL, Polle A, Lea PJ, Azevedo RA (2005) Making the life of heavy metal-stressed plants a little easier. Functional Plant Biology 32, 481-494

Green MR (1991) Biochemical mechanisms of constitutive and regulated pre-mRNA splicing. Annual Review of Cell Biology 7, 559-599

Grotz N, Fox T, Connolly E, Park W, Guerinot ML, Eide D (1998) Identification of a family of zinc transporter genes from Arabidopsis that respond to zinc deficiency. Proceedings of the National Academy of Science, USA 95, 7220-7224

Guo Y, Smith K, Lee J, Thiele DJ, Petris MJ (2004) Identification of methionine-rich clusters that regulate copper-stimulated endocytosis of the human Ctr1 copper transporter. Journal of Biological Chemistry 279, 17428-17433

Guo W-Y, Meetam M, Goldsbrough PB (2008) Examining the specific contributions of individual Arabidopsis metallothioneins to copper distribution and metal tolerance. Plant Physiology 146, 1697-1706

Gupta M, Cuypers A, Vangronsveld J, Clijsters H (1999) Copper affects the enzymes of the ascorbate-glutathione cycle and its related metabolites in the roots of Phaseolus vulgaris. Physiologia Plantarum 106, 262-267

Hall JL (2002) Cellular mechanisms for heavy metal detoxification and tolerance. Journal of Experimental Botany 53, 1-11

Halliwell B, Gutteridge JMC (1984) Oxygen toxicity, oxygen radicals, transition metals and disease. Biochemical Journal 219, 1-14

Harris ED (2000) Cellular copper transport and metabolism. Annual Review of Nutrition 20, 291-310 Haydon MJ, Cobbet CS (2007) A novel major facilitator superfamily protein at the tonoplast influences Zn tolerance and accumulation in Arabidopsis thaliana. Plant Physiology 143, 1705-1719 
Henriques FS (1989) Effects of copper deficiency on the photosynthetic apparatus of sugar beet (Beta vulgaris L.) Journal of Plant Physiology 135, 453-458

Herbik A, Bölling C, Buckhout TJ (2002) The involvement of a multicopper oxidase in iron uptake by the green algae Chlamydomonas reinhardtii. Plant Physiology 130, 2039-2048

Himelblau E, Mira H, Lin SJ, Culotta VC, Peñarrubia L, Amasino RM (1998) Identification of a functional homolog of the yeast copper homeostasis gene ATX1 from Arabidopsis. Plant Physiology 117, 1227-1234

Himelblau E, Amasino RM (2000) Delivering copper within plant cells. Current Opinion of Plant Biology 3, 205-210

Hinsinger P, Courchesne F (2007) Mobility and bioavailability of heavy metals and metalloids at soil-root interface. In: "Biophysico-chemical processes of heavy metals and metalloids in soil environments, Vol 1" (Eds A Violante, PM Huang, GM Gadd) (Wiley-IUPAC Series Biophisico-Chemical processes in Environmental Systems: Chichester, UK)

Hirayama T, Kieber JJ, Hirayama N, Kogan M, Guzman P, Nourizadeh S, Alonso JM, Dailey WP, Dancis A, Ecker JR (1999) Responsive-to antagonistst1, a Menkes/Wilson disease-related copper transporter, is required for ethylene signaling in Arabidopsis. Cell 97, 383-393

Hirayama T, Alonso JM (2000) Ethylene captures a metal! Metal ions are involved in ethylene perception and signal transduction. Plant Cell Physiology 41, 548-555

Huffman DL, O’Halloran TV (2001) Function, structure, and mechanism of intracellular copper trafficking proteins. Annual Review of Biochemistry 70, 677-701

Jonak C, Nakagami H, Hirt H (2004) Heavy metal stress. Activation of distinct mitogen-activated protein kinase pathways by copper and cadmium. Plant Physiology 136, 3276-3283

Jones JB (1998) Plant Nutrition Manual, CRC Press, pp 1-149

Kabata-Pendias A, Pendias H (2001). Trace elements in soil and plants. Boca Raton, FL CRC Press. Kaiser BN, Moreau S, Castelli J, Thomson R, Lambert A, Bogliolo S, Puppo A, Day DA (2003) The 
soybean NRAMP homologue, GmDMT1 is a symbiotic divalent metal transporter capable of ferrous iron transport. Plant Journal 35, 295-304

Kampfenkel K, Kushinr S, Babychuk E, Inzé D, van Montagu M (1995) Molecular characterization of a putative Arabidopsis thaliana copper transporter and its yeast homologue. Journal of Biological Chemistry 270, 28479-28486

Kanematsu S, Asada K (1989) CuZn-superoxide dismutase in rice: occurrence of an active, monomeric enzyme and two types of isoenzymes in leaf and non-photosynthetic tissues. Plant Cell Physiology 30, 381-391

Kazan K (2003). Alterantive splicing and proteome diversity in plants: the tip of iceberg has just emerged. Trends in Plant Science 8, 468-471

Keinämen SI, Hassinen VH, Kärenlampi SO, Tervahauta AI (2007) Isolation of genes up-regulated by copper in a copper-tolerant birch (Betula pendula) clone. Tree Physiology 27, 1243-1252 Kernodle and Scandalios (2001) Structural organization, regulation, and expression of the chloroplastic superoxide dismutase Sod1 gene in maize. Archives of Biochemistry and Biophysics 391,137-147

Kieselbach T, Hagman Á, Andersson, Schröder WP (1998) The thylakoid lumen of the chloroplasts: isolation and characterization. Journal of Biological Chemistry 273, 6710-6716

Kishinami I, Widholm JM (1987) Characterization of $\mathrm{Cu}$ and Zn resistant Nicotiana plumbaginifolia suspension cultures. Plant Cell Physiology 28, 203-210

Kitagishi K, Yamane I (1981) Heavy metal pollution in soils of Japan (eds Kitahishi K and Yamane I) Japan Science Society Press, Tokyo pp 1-302.

Klomp AE, Juijn JA, van der Gun LT, van den Berg IE, Berger R, Klomp LW (2003) The Nterminus of the human copper transporter 1 (hCTR1) is localized extracellularly, and interacts with itself. Biochemical Journal 370, 881-889

Kobayashi Y, Kuroda K, Kimura K, Southron-Francis JL, Furuzawa A, Kimura K, Iuchi S, 
Kobayashi M, Taylor GJ, Koyama H (2008) Amino acid polymorphisms in strictly conserved domains of a P-type ATPase HMA5 are involved in the mechanism of copper tolerance variation in Arabidopsis. Plant Physiology 148, 969-980

Kochian LV (1991) Mechanisms of micronutrient uptake and translocation in plants. In:

“Micronutrients in agriculture”. (Eds. JJ Mortvedt, FR Cox, LM Shuman, RM Welch) pp. 229-296 (Soil Science Society of America: Madison, WI)

Koike S, Inoue H, Mizuno D, Takahashi M, Nakanishi H, Mori S, Nishizawa NK (2004) OsYSL2 is a rice metal-nicotianamine transporter that is regulated by iron and expressed in the phloem. Plant Journal 39, 415-424

Krämer U, Clemens S (2006) Functions and homeostasis of zinc, copper, and nickel in plants. In: Tamás M, Martinoia E (eds) Molecular Biology of Metal Homeostasis and Detoxification from Microbes to Man. Berlin, Springer, pp 214-272

Kropat J, Tottey S, Birkenbihl RP, Depege N, Huijser P, Merchant S (2005) A regulator of nutritional copper signaling in Chlamydomonas is an SBP domain protein that recognizes the GTAC core of copper response element. Proceedings of the National Academy of Science, USA 102, 18730-18735

Kühlbrandt W (2004) Biology, structure and mechanism of P-type ATPases. Nature Reviews Molecular Cell Biology 5, 282-295

Kuper J, Llamas A, Hecht HJ, Mendel RR, Schwarz G (2004) Structure of the molybdopterin-bound Cnx1G domain links molybdenum and copper metabolism. Nature 430, 803-806

Küpper H, Šetlík I, Šetliková E, Ferimazova N, Spiller M, Küpper FC (2003) Copper-induced inhibition of photosynthesis: limiting steps of in vivo copper chlorophyll formation in Scenedesmus quadricauda. Functional Plant Biology 30, 1187-1196

Küpper H, Kroneck PMH (2005) Heavy metal uptake by plants and cyanobacteria. Metal ions in Biological Systems 44, 97-144 
La Fontaine S, Quinn JM, Nakamoto SS, Page MD, Göhre V, Moseley JL, Kropat J, Merchant S, (2002) Copper-dependent iron assimilation pathway in the model photosynthetic eukaryote Chlamydomonas reinhardtii. Eukariotic Cell 1, 736-757

Labbé S, Zhu Z, Thiele DJ (1997) Copper-specific transcriptional repression of yeast genes encoding critical components in the copper transport pathway. Journal of Biological Chemistry 272, 15951-15958.

Labbé S, Thiele DJ (1999) Pipes and wiring: the regulation of copper uptake and distribution in yeast. Trends in Microbiology 7, 500-505

Lanaras T, Moustakas M, Symeonidis L, Diamantoglou S, Karataglis S (1993) Plant metal content, growth responses and some photosynthetic measurements on field-cultivated wheat growing on ore bodies enriched in Cu. Physiologia Plantarum 88, 307-314.

Lee J, Peña MM, Nose Y, Thiele DJ (2002) Biochemical characterization of the human copper transporter Ctr1. Journal of Biological Chemistry 277, 4380-4387

Le Jean M, Schikora A, Mari S, Briat JF, Curie C (2005) A loss-of-function mutation in AtYSL1 reveals its role in iron and nicotianamine seed loading. Plant Journal 44, 769-782

Lidon FC, Henriques FS (1991) Limiting step in photosynthesis of rice plants treated with varying copper levels. Journal of Plant Physiology 138,115-118

Lidon FC, Henriques FS (1993) Changes in the thylakoid membrane polypeptide patterns triggered by excess $\mathrm{Cu}$ in rice. Photosynthetica $\mathbf{2 8}, 109-117$

Lightbody JJ, Krogmann DW (1967) Isolation and properties of plastocyanin from Anabaena variabilis. Biochimica et Biophysica Acta 131, 508-515

Ling HQ, Pich A, Scholz G, Ganal MW (1996) Genetic analysis of two tomato mutants affected in the regulation of iron metabolism. Molecular and General Genetics 252, 87-92

López-Millán AF, Ellis DR, Grusak MA (2004) Identification and characterization of several new members of the ZIP family of metal ion transporters in Medicago truncatula. Plant 
Molecular Biology 54, 583-596

Lombardi L, Sebastiani L (2005) Copper toxicity in Prunus cerasifera: growth and antioxidant enzymes responses of in Vitro grown plants. Plant Science 168, 797-802

Luna CM, González CA, Trippi VS (1994) Oxidative damage caused by excess of copper in oat leaves. Plant Cell Physiology 35, 11-15

Lutsenko S, Barnes NJ, Bartee MY, Dmitriev OL (2007) Function and regulation of Human coppertransporting ATPases. Physiological Reviews 87, 1011-1046.

Maksymiec W, Russa R, Urbanik-Sypniewska T, Baszynski T (1994) Effect of excess Cu on the photosynthetic apparatus of runner bean leaves treated at two different growth stages.

Physiologia Plantarum 91, 715-721

Mariano ED, Jorge RA, Keltjens WG, Menossi M (2005) Metabolism and root exudation of organic acid anions under aluminium stress. Brazilian Journal of Plant Physiology 17, 157-172

Markossian KA, Kurganov BI (2003) Copper chaperones, intracellular copper trafficking proteins. Function, structure, and mechanism of action. Biochemistry (Mosc) 68, 827-837

Marschner H (1995) Mineral nutrition of higher plants. Academic Press, London, pp 344-346

Mäser P, Thomine S, Schroeder JI, Ward JM, Hirschi K, Sze H, Talke IN, Amtmann A, Maathuis FJ, Sanders D, Harper JF, Tchieu J, Gribskov M, Persans MW, Salt DE, Kim SA, Guerinot ML (2001) Phylogenetic relationships within cation transporter families of Arabidopsis. Plant Physiology 126, 1646-1667

Mendel RR (2005) Molybdenum: biological activity and metabolism. Dalton Transaction 21, 34043409

Mengoni A, Gonnelli C, Hakvoort HWJ, Galardi F, Bazzicalupo M, Gabbrielli R, Schat H (2003) Evolution of copper-tolerance and increased expression of a $2 b$-type metallothionein gene in Silene paradoxa L.populations. Plant and Soil 257, 451-457

Merchant S, Bogorad L (1986a) Rapid degradation of apoplastocyanin in Cu(II)-deficient cells of 
Chlamydomonas reinhardtii. Journal of Biological Chemistry 261, 15850-15853

Merchant S, Bogorad L (1986b) Regulation by copper of the expression of plastocyanin and cytochrome c552 in Chlamydomonas reinhardtii. Molecular Cell Biology 6, 462-469

Michaud AM, Bravin MN, Galleguillos M, Hinsinger P (2007) Copper uptake and phytotoxicity as assessed in situ for durum wheat (Triricum turgidum durum L.) cultivated in $\mathrm{Cu}-$ contaminated, former vineyard soils. Plant and Soil 298, 99-111

Mira H, Martínez-García F, Peñarrubia L (2001a) Evidence for the plant-specific intercellular t ransport of the Arabidopsis copper chaperone CCH. Plant Journal 25, 521-528

Mira H, Vilar M, Pérez-Raya E, Peñarrubia L (2001b) Functional and conformational properties of the exclusive C-domain from the Arabidopsis copper chaperone (CCH). Biochemical Journal $15: 545-549$

Mira H, Vilar M, Esteve V, Martinell M, Kogan MJ Giralt E, Salom D, Mingarro I, Peñarrubia L, Pérez-Paya E (2004) Ionic self-complementarity induces amyloid-like fibril formation in an isolated domain of a plant copper metallochaperone protein. BMC Structural Biology 4:7

Moller SG, McPherson MJ (1998) Developmental expression and biochemical analysis of the Arabidospsis ataol gene encoding and $\mathrm{H}_{2} \mathrm{O}_{2}$-generating diamine oxidase. Plant J 13:781-791

Mori S (1999) Iron acquisition by plants. Current Opinion in Plant Biology 2, 250-253

Moseley JL, Page MD, Alder NP, Eriksson M, Quinn J, Soto F, Theg SM, Hippler M,

Merchant S (2002) Reciprocal expression of two candidate di-iron enzymes affecting photosystem I and light-harvesting complex accumulation. Plant Cell 14, 673-688

Mukherjee I, Campbell NH, Ash JS, Connolly EL (2006) Expression profiling of the Arabidopsis ferric chelate reductase (FRO) gene family reveals differential regulation by iron and copper. Planta 223, 1178-1190

Murphy A, Taiz L (1995) A new vertical mesh transfer technique for metal-tolerance studies in Arabidopsis. Plant Physiology 108, 29-38 
Murphy AS, Eisenger WR, Shaff JE, Kochian LV, Taiz L (1999) Early copper-induced leakage of

$\mathrm{K}^{+}$from Arabidopsis seedlings is mediated by ion channels and coupled to citrate efflux. Plant Physiology 121, 1375-1382

Nagae M, Nakata M, Takahashi Y (2008) Identification of negative cis-acting elements in response to copper in the chloroplastic iron superoxide dismutase gene of the Moss Barbula unguiculata. Plant Physiology 146, 1687-1696

Navari-Izzo F, Quartacci MF, Pinzino C, Dalla Vecchia F, Sgherri CLM (1998) Thylakoid-bound and stromal enzymes in wheat treated with excess copper. Physiologia Plantarum 104, 630638

Nerissian AM, Immoos C, Hill MG, Hart PJ, Williams G, Herrmann RG, Valentine JS (1998) Uclacyanins, stellacyanins and plantacyanins are distinct subfamilies of phytocyanins: Plantspecific mononuclear blue copper proteins. Protein Science 7, 1915-1929

O’Halloran TV, Culotta VC (2000) Metallochaperones, an intracellular shuttle service for metal ions. Journal of Biological Chemistry 275, 25057-25060

Ouzounidou G, Eleftheriou EP, Karataglis S (1992) Ecophysiological and ultraestructural effects of copper in Thlaspi ochroleucum (Cruciferae). Canadian Journal of Botany 70, 947-957

Palmgren MG, Axelsen KB (1998) Evolution of P-type ATPases. Biochimica et Biophysica Acta 1365, 37-45

Panou-Filotheou H, Bosabalidis AM, Karataglis S (2001) Effects of copper toxicity on leaves of oregano (Origanum vulgare subsp. hirtum). Annals of Botany 88, 207-214

Panou-Filotheou H, Basabalidis AM (2004) Root structural aspects associated with copper toxicity in oregano (Origanum vulgare subsp. hirtum). Plant Science 166, 1497-1504

Pätsikkä E, Aro E-M, Tyystjärvi E (1998) Increase in the quantum yield of photoinhibition contributes to copper toxicity in vivo. Plant Physiology 117, 619-627

Pätsikkä E, Kairavuo M, Sersen F, Aro E-M, Tyystjärvi E (2002) Excess copper predisposes 
photosystem II to photoinhibition in vivo by outcompeting iron and causing decrease in leaf chlorophyll. Plant Physiology 129, 1359-1367

Peña MMO, Lee J, Thiele DJ (1999) A delicate balance: homeostatic control of copper uptake and distribution. Journal of Nutrition 129, 1251-1260

Pilon M, Abdel-Ghany SE, Cohu CM, Gogolin KA, Ye H (2006) Copper cofactor delivery in plant cells. Current Opinion of Plant Biology 9, 1-8

Pilon-Smits E, Pilon M (2002) Phytoremediation of metals using transgenic plants. Critical Reviews in Plant Sciences 21, 439-456

Prasad MNV, Strzalka K (1999) Impact of heavy metals on photosynthesis. In: Prasad MNV, Hagemeyer J (eds) Heavy Metal Stress in Plants, Springer Publishers, Berlin, pp 117-138

Pufahl RA, Singer CP, Peariso KL, Lin SJ, Schmidt PJ, Fahrni CJ, Culotta VC, Penner-Hahn JE, O'Halloran TV (1997) Metal ion chaperone function of the soluble Cu(I) receptor Atx1. Science 278, 853-856

Puig S, Thiele DJ (2002) Molecular mechanisms of copper uptake and distribution. Current Opinion in Chemical Biology 6, 171-180

Puig S, Andrés-Colás N, García-Molina A, Peñarrubia L (2007) Copper and iron homeostasis in Arabidopsis: responses to metal deficiencies, interactions and biotechnological applications. Plant Cell and Environment 30, 271-290

Quartacci MF, Pinzino C, Sgherri CLM, Dalla Vecchia F, Navari-Izzo F (2000) Growth in excess copper induces changes in the lipid composition and fluidity of PSII-enriched membranes in wheat. Physiologia Plantarum 108, 87-93

Quinn JM, Barraco P, Eriksson M, Merchant S (2000) Coordinate copper- and oxygen-responsive Cyc6 and Cpx1 expression in Chlamydomonas is mediated by the same element. Journal of Biological Chemistry 275, 6080-6089

Quinn JM, Eriksson M, Moseley JL, Merchant S (2002) Oxygen deficiency responsive gene 
expression in Clamydomonas reinhardtii through a copper-sensing signal transduction pathway. Plant Physiology 128, 463-471

Radisky D, Kaplan J (1999) Regulation of transition metal transport across the yeast plasma membrane. Journal of Biological Chemistry 274, 4481-4484

Ramocha P, Chabannes M, Chamayou S, Danoun S, Jauneau A, Boudet AM, Goffner D (2002) Laccase down-regulation causes alterations in phenolic metabolism and cell wall structure in poplar. Plant Physiology 129, 145-155

Raven JA, Evans MCW, Korb RE (1999) The role of trace metals in photosynthetic electron transport in $\mathrm{O}_{2}$-evolving organisms. Photosynthesis Research 60, 111-149

Reeve WG, Tiwari RP, Kale NB, Dilworth MJ, Glenn AR (2002) ActP controls copper homeostasis in Rhizobium legominosarum bv. viciae and Sinorhizobium meliloti preventing low pH-induced copper toxicity. Molecular Microbiology 43, 981-991

Roberts LA, Pierson AJ, Panaviene Z, Walker EL (2004) Yellow stripe1. Expanded roles for the maize iron-phytosiderophore transporter. Plant Physiology 135, 112-120

Rodríguez FI, Esch JJ, Hall AE, Binder BM, Schaller GE, Bleecker AB (1999) A copper cofactor for the ethylene receptor ETR1 from Arabidopsis. Science 283, 996-998

Römheld V (1991) The role of phytosiderophores in acquisition of iron and other micronutrients in gramineous species -an ecological approach. Plant and Soil 130, 127-134

Rombolà AD, Gogorcena Y, Larbi A, Morales F, Balde E, Marangoni B, Tagliavini M, Abadía J (2005) Iron deficiency-induced changes in carbon fixation and leaf elemental composition of sugar beet (Beta vulgaris) plants. Plant and Soil 271, 39-45

Rutherford JC, Bird AJ (2004) Metal-responsive transcription factors that regulate iron, zinc, and copper homeostasis in eukaryotic cells. Eukaryotic Cell 3, 1-13

Ruzsa SM, Scandalios JG (2003) Altered Cu metabolism and differential transcription of Cu/ZnSod genes in a $\mathrm{Cu} / \mathrm{ZnSOD}$-deficient mutant of maize: evidence for a $\mathrm{Cu}$-responsive transcription 
factor. Biochemistry 42, 1508-1516

Sadmann G, Böger P (1980) Copper-mediated lipid peroxidation processes in photosynthetic membranes. Plant Physiology 66, 797-800.

Salim R, Al-Subu MM, Douleh A, Chenavier L, Hagemeyer J (1992) Effects of root and foliar treatments on carrot plants with lead and cadmium on the growth, uptake and the distribution of metals in treated plants. Journal of Environmental Science and Health, Part A 27, 17391758

Sancenón V, Puig S, Mira H, Thiele DJ, Peñarrubia L (2003) Identification of a copper transporter family in Arabidopsis thaliana. Plant Molecular Biology 51, 577-587

Sancenón V, Puig S, Mateu-Andrés I, Dorcey E, Thiele DJ, Peñarrubia L (2004) The Arabidopsis copper transporter COPT1 functions in root elongation and pollen development. Journal of Biological Chemistry 279, 15348-15355

Sauvé S, McBride MB, Norvell WA, Hendershot WH (1997) Copper solubility and speciation of in situ contaminated soils: effects of copper level, $\mathrm{pH}$ and organic matter. Water Air and Soil Pollution 100, 133-149

Schaaf G, Ludewig U, Erenoglu BE, Mori S, Kitahara T, von Wiren (2004) ZmYS1 functions as a proton-coupled symporter for photosyderophore- and nicotianamine-chelated metals. Journal of Biological Chemistry 279, 9091-9096

Schaaf G, Schikora A, Harberle J, Vert G, Ludewig U, Briat JF, Curie C, von Wiren N (2005) A putative function for the Arabidopsis Fe-Phytosiderophore transporter homolog AtYSL2 in Fe and Zn homeostasis. Plant Cell Physiology 46, 762-774

Schiavon M, Zhang LH, Abdel-Ghany SE, Pilon M, Malagoli M, Pilon-Smits EAH (2007) Variation in copper tolerance in Arabidopsis thaliana accessions Columbia, Landsberg erecta and Wassilewskija. Physiologia Plantarum 129, 342-350

Schmidt W (1999) Mechanisms and regulation of reduction-based iron uptake in plants. New 
Phytologist 141, 1-26

Schubert M, Petersson UA, Haas BJ, Funk C, Schroder WP, Kieselbach T (2002) Proteome map of the chloroplast lumen of Arabidopsis thaliana. Journal of Biological Chemistry 277, 83548365

Sedbrook JC, Carroll KL, Hung KF, Masson PH, Somerville CR (2002) The Arabidpsis SKU5 gene encodes an extracellular glycosyl phosphatidylinositol-anchored glycoprotein involved in directional root growth plant cell. The Plant Cell 14, 1635-1648.

Seigneurin-Berny D, Gravot A, Auroy P, Mazard C, Kraut A, Finazzi G, Grunwald D, Rappaport F, Vavasseur A, Joyard J, Richaud P, Rolland NJBC (2006) HMA1, a new Cu-ATPase of the chloroplast envelope, is essential for growth under adverse light conditions. Journal of Biological Chemistry 28, 2882-2892

Shikanai T, Müller-Moulé P, Munekage Y, Niyogi KK, Pilon M (2003) PPA1, a P-type ATPase of Arabidopsis, functions in copper transport in chloroplasts. Plant Cell 15, 1333-1346

Sichul L, Yu-Young K, Youngsook L, Gynheung A (2007) Rice $\mathrm{P}_{1 \mathrm{~B}}$-ATPase, OsHMA9, is a metal efflux protein. Plant Physiology 145, 831-842

Solioz M, Vulpe (1996) CPx-type ATPases: a class of P-type ATPases that pump heavy metals. Trends in Biochemical Science 21, 237-241

Southron JL, Basu U, Taylor GJ (2004) Complementation of Saccharomyces cerevisiae ccc2 mutant by a putative P1B-ATPase from Brassica napus supports a copper-transporting function. FEBS Letters 566, 218-222

Stohs SJ, Bagchi D (1995) Oxidative mechanisms in the toxicity of metal ions. Free Radicals in Biology and Medicine 18, 321-336

Sudo E, Itouga M, Yoshida-Hatanaka K, Ono Y, Sakakibara H (2008) Gene expression and sensitivity in response to copper stress in rice leaves. Journal of Experimental Botany 59, 3465-3474 
Sunkar R, Kapoor A, Zhu JK (2006) Posttranscriptional induction of two Cu/Zn superoxide dismutase genes in Arabidopsis is mediated by downregulation of miR398 and important for oxidative stress tolerance. Plant Cell 18, 2066-2081

Tabata K, Kashiwagi S, Mori H, Ueguchi C, Mizuno T (1997) Cloning of a cDNA encoding a putative metal-transporting P-type ATPase from Arabidopsis thaliana. Biochimica et Biophysica Acta: Biomembranes 1326, 1-6

Takahashi M, Terada Y, Nakai I, Nakanishi H, Yoshimura E, Mori S, Nishizawa NK (2003) Role of nicotianamine in the intracellular delivery of metals and plant reproductive development. Plant Cell 15, 1263-1280

Thomas JC, Davies EC, Malick FK, Endreszi C, Williams CR, Abbas M, Petrella S, Swisher K, Perron M, Edwards R, Osenkowski P, Urbanczyk N, Wiesend WN, Murray KS (2003) Yeast metallothionein in transgenic tobacco promotes copper uptake from contaminated soils. Biotechnology Progress 19, 273-280

Trindade LM, Horváth BM, Bergervoet MJE, Visser RGF (2003) Isolation of a gene encoding a copper chaperone for copper/zinc superoxide dismutase and characterization of its promoter in potato. Plant Physiology 133, 618-629

Van Assche F, Clijsters H (1990) Effects of metals on enzyme activity in plants. Plant Cell and Environment 13, 195-206

Van Hoof NA, Hassinen VH, Hakvoort HW, Ballintijn KF, Schat H, Verkleij JA, Ernst WH, Karenlampi SO, Tervahauta AI (2001) Enhanced copper tolerance in Silene vulgaris (Moench) Garcke populations from copper mines is associated with increased transcript levels of a 2b-type metallothionein gene. Plant Physiology 126, 1519-1526

Van Tichelen KK, Colpaert JV, Vangronsveld J (2001) Ectomycorrhizal protection of Pinus sylvestris against copper toxicity. New Phytologist 150, 203-213

Van Vliet C, Anderson CR, Cobbet CS (1995) Copper-sensitive mutant of Arabidopsis thaliana. 
Plant Physiology 109, 871-878

Vitória AP, Cunha M, Azevedo RA (2006) Ultrastructural changes of radish leaf exposed to cadmium. Environmental and Experimental Botany 58, 47-52

Von Wiren N, Klair S, Bansal S, Briat JF, Khodr H, Shioiri T, Leigh RA, Hider RC (1999)

Nicotianamine chelates both Fe (III) and Fe(II). Implications for metal transport in plants.

Plant Physiology 119, 1107-1114

Wallace A, Cha JW (1989) Interactions involving copper toxicity and phosphorous deficiency in bush bean plants grown in solutions of of low and high pH. Soil Science 147, 430-431

Wang H, Shan X-q, Wen B, Zhang S, Wang Z-j (2004) Responses of antioxidative enzymes to accumulation of copper in a copper hyperaccumulator of Commoelina communis. Archives of Environmental Contamination and Toxicology 47, 185-192

Waters BM, Chu H-H, DiDonato RJ, Roberts LA, Eisley RB, Lahner B, Salt DE, Walker EL (2006) Mutations in Arabidopsis Yellow Stripe-Like1 and Yellow Stripe-Like3 reveal their roles in metal ion homeostasis and loading of metal ions in seeds. Plant Physiology 141, 1446-1458

Weber M, Trampczynska A, Clemens S (2006) Comparative transcriptome analysis of toxic metal responses in Arabidopsis thaliana and the $\mathrm{Cd}^{2+}$-hypertolerant facultative metallophyte Arabidopsis halleri. Plant Cell and Environment 29, 950-963

Weigel M, Varotto C, Pesaresi P, Finazzi G, Rappaport F, Salamini F, Leister D (2003) Plastocyanin is indispensable for photosynthetic electron flow in Arabidopsis thaliana. Journal of Biological Chemistry 278, 31286-31289

Williams LE, Pittman JK, Hall JL (2000) Emerging mechanisms for heavy metal transport in plants. Biochimica et Biophysica Acta 1465, 104-126

Williams LE, Mills RF (2005) $\mathrm{P}_{1 \mathrm{~B}}$-ATPases - an ancient family of transition metal pumps with diverse functions in plants. Trends in Plant Science 10, 491-502

Wintz H, Vulpe C (2002) Plant copper chaperones. Biochemical Society Transactions 30, 732-735 
Wintz H, Fox T, Wu YY, Feng V, Chen WQ, Chang HS, Zhu T, Vulpe C (2003) Expression profiles of Arabidopsis thaliana in mineral deficiencies reveal novel transporters involved in metal homeostasis. Journal of Biological Chemistry 278, 47644-47653

Woeste KE, Kieber JJ (2000). A strong loss of function mutation in RAN1 results in constitutive activation of the ethylene response pathway as well as rosette-lethal phenotype. Plant Cell $12,443-455$

Wójcik M, Tukiendorf A (2003) Response of wild type of Arabidopsis thaliana to copper stress. Biologia Plantarum 46, 79-84

Yamasaki H, Abdel-Ghany SE, Cohu CM, Kobayashi Y, Shikanai T, Pilon M (2007) Regulation of copper homeostasis by micro-RNA in Arabidopsis. Journal of Biological Chemistry 282, 16369-16378

Yamasaki H, Hayashi M, Fukazawa M, Kobayashi Y, Shikanai T (2009) SQUAMOSA promoter binding proein-like7 is a central regulator for copper homeostasisin Arabidopsis. The Plant Cell, doi: 10.1105/tpc.108.060137

Yen M-R, Tseng Y-H, Saier MH Jr (2001) Maize Yellow Stripe1, an iron-phytosiderophore uptake transporter, is a member of the oligopeptide transporter (OPT) family. Microbiology 147, 2881-2883

Yruela I, Pueyo JJ, Alonso PJ, Picorel R (1996) Photoinhibition of photosystem II from higher plants: effect of copper inhibition. Journal of Biological Chemistry 271:27408-27415

Yruela I (2005) Copper in plants. Brazilian Journal of Plant Physiology 17,145-146

Zhou J, Goldsbrough PB (1995) Structure, organization and expression of the metallothionein gene family in Arabidopsis. Molecular and General Genomics 248, 318-328

Zhu Z, Labbé S, Peña MM, Thiele DJ (1998) Copper differentially regulates the activity and degradation of yeast Mac1 transcription factor. Journal of Biological Chemistry 273, 12771280 
Zhu H, Shipp E, Sanchez RJ, Liba A, Stine JE, Hart PJ, Gralla EB, Nersissian AM, Valentine JS (2000) Cobalt $(2+)$ binding to human and tomato copper chaperone for superoxide dismutase: implications for the metal ion transfer mechanism. Biochemistry 39, 5413-5421

\section{FIGURE LEGENDS}

Figure 1. Scheme of transport pathways identified for $\mathrm{Cu}$ in a generic plant cell. $\mathrm{Cu}-$ membrane transporter proteins are indicated in orange, $\mathrm{Cu}$-chaperones in violet, and $\mathrm{Cu}$-proteins in blue. Arrows indicate the proposed direction for metal transport. $\mathrm{CCH}$, copper chaperone; ATX1, antioxidant 1; $\mathrm{CCS}$, copper chaperone for $\mathrm{Cu} / \mathrm{Zn}$ superoxide dismutase; $\mathrm{CSD} 1$, cytosolic $\mathrm{Cu} / \mathrm{Zn}$ superoxide dismutase; $\mathrm{CSD}$ 2, chloroplastic $\mathrm{Cu} / \mathrm{Zn}$ superoxide dismutase; CSD3, peroxisomal $\mathrm{Cu} / \mathrm{Zn}$ superoxide dismutase; COPT, copper transporter; COX, cytochrome-c oxidase; ER, endoplasmic reticulum; FRO, ferric reductase oxidase; HMA, heavy metal P-type ATPase; MT, metallothioneins; NA, nicotianamine; PAA, P-type ATPase of Arabidopisis; Pc, plastocyanin; RAN1, responsive-toantagonist 1; SOD, superoxide dismutase; YSL, yellow stripe-like protein; ZIP, IRT-like protein. Scheme modified from Pilon et al. (2006), Puig et al. (2007), Bernal (2006a).

Figure 2. Predicted membrane topology for several members of COPT and $\mathrm{P}_{1 \mathrm{~B}}$-ATPase (HMA) families $\mathrm{Cu}$-transporters. This topology is based on predictions but has not been verified experimentally. 
TABLE 1. Copper homeostasis proteins in plants

\begin{tabular}{|c|c|c|c|c|c|}
\hline Family & Name & Description & Subcellular localization & Tissue expression & Referentes \\
\hline ZIP & $\begin{array}{l}\text { AtZIP2 } \\
\text { AtZIP4 } \\
\text { MtZIP4 }\end{array}$ & $\begin{array}{l}\text { Divalent cation transporter } \\
\text { Divalent cation transporter } \\
\text { Divalent cation transporter }\end{array}$ & $\begin{array}{l}\text { Plasma membrane? } \\
\text { Plasma membrane? }\end{array}$ & $\begin{array}{l}\text { Root } \\
\text { Root, leaf }\end{array}$ & López-Millán et al. (2004) \\
\hline COPT & $\begin{array}{l}\text { AtCOPT1 } \\
\text { AtCOPT2 } \\
\text { AtCOPT3 } \\
\text { AtCOPT5 } \\
\text { AtCOPT6 }\end{array}$ & $\begin{array}{l}\text { High-affinity } \mathrm{Cu}^{+} \text {transporter } \\
\text { High-affinity } \mathrm{Cu}^{+} \text {transporter } \\
\text { High-affinity } \mathrm{Cu}^{+} \text {transporter } \\
\text { High-affinity } \mathrm{Cu}^{+} \text {transporter }\end{array}$ & $\begin{array}{l}\text { Plasma membrane? } \\
\text { Plasma membrane? } \\
\text { Chloroplast? } \\
\text { Secretory pathway? }\end{array}$ & $\begin{array}{l}\text { Root, pollen, embryo, stomata, } \\
\text { trichome }\end{array}$ & $\begin{array}{l}\text { Kampfenkel et al. (1995); Sancenón et al. (2004) } \\
\text { Sancenón et al. (2003) }\end{array}$ \\
\hline $\mathrm{P}_{1 \mathrm{~B}}$-ATPase & $\begin{array}{l}\text { AtHMA1 } \\
\text { AtHMA5 } \\
\text { OsHMA5 } \\
\text { AtHMA6(PAA1) } \\
\text { OsHMA6 } \\
\text { AtHMA7(RAN1) } \\
\text { BnHMA7(BnRAN1) } \\
\text { OsHMA7 } \\
\text { AtHMA8(PAA2) } \\
\text { GmHMA8 } \\
\text { OsHMA8 } \\
\text { OsHMA9 }\end{array}$ & $\begin{array}{l}\mathrm{Cu}^{2+}-\mathrm{P}_{1 \mathrm{~B}}-\mathrm{ATP} \text { ase transporter? } \\
\mathrm{Cu}^{+}-\mathrm{P}_{1 \mathrm{~B}}-\mathrm{ATP} \text { ase transporter } \\
\mathrm{Cu}^{+}-\mathrm{P}_{1 \mathrm{~B}}-\mathrm{ATP} \text { ase transporter } \\
\mathrm{Cu}^{+}-\mathrm{P}_{1 \mathrm{~B}}-\mathrm{ATP} \text { ase transporter } \\
\mathrm{Cu}^{+}-\mathrm{P}_{1 \mathrm{~B}}-\mathrm{ATP} \text { ase transporter } \\
\mathrm{Cu}^{+}-\mathrm{P}_{1 \mathrm{~B}}-\mathrm{ATPase} \text { transporter } \\
\mathrm{Cu}^{+}-\mathrm{P}_{1 \mathrm{~B}}-\mathrm{ATPase} \text { transporter } \\
\mathrm{Cu}^{+}-\mathrm{P}_{1 \mathrm{~B}}-\mathrm{ATPase} \text { transporter } \\
\mathrm{Cu}^{+}-\mathrm{P}_{1 \mathrm{~B}}-\mathrm{ATPase} \text { transporter } \\
\mathrm{Cu}^{+}-\mathrm{P}_{1 \mathrm{~B}}-\mathrm{ATPase} \text { transporter } \\
\mathrm{Cu}^{+}-\mathrm{P}_{1 \mathrm{~B}}-\mathrm{ATPase} \text { transporter } \\
\mathrm{Cu}^{+}-\mathrm{P}_{1 \mathrm{~B}}-\mathrm{ATPase} \text { transporter }\end{array}$ & $\begin{array}{l}\text { Chloroplast envelope } \\
\text { Secretory pathway? } \\
\text { Secretory pathway? } \\
\text { Chloroplast envelope } \\
\text { Chloroplast envelope } \\
\text { Trans-Golgi network? } \\
\text { Trans-Golgi network? } \\
\text { Trans-Golgi network? } \\
\text { Thylakoid membrane } \\
\text { Thylakoid membrane } \\
\text { Thylakoid membrane } \\
\text { Plasma membrane }\end{array}$ & $\begin{array}{l}\text { Root, shoot } \\
\text { Root, flower, pollen } \\
\text { Root } \\
\text { Root, shoot } \\
\text { Root, shoot, leaf } \\
\text { Root, shoot, leaf } \\
\text { Shoot } \\
\text { Leaf, mesophyll cell } \\
\text { Root, shoot, leaf } \\
\text { Vascular tissue (phloem, } \\
\text { xylem), mesophyll tissues, } \\
\text { anthers }\end{array}$ & $\begin{array}{l}\text { Seigneurin-Berny et al. (2006) } \\
\text { Andrés-Colás et al. (2006) } \\
\text { Sichul et al. (2007) } \\
\text { Shikanai et al. (2003); Abdel-Ghany et al. (2005b) } \\
\text { Sichul et al. (2007) } \\
\text { Hirayama et al. (1999); Woeste and Kieber (2000; Chen } \\
\text { et al. (2002) } \\
\text { Southron et al. (2004) } \\
\text { Sichul et al. (2007) } \\
\text { Abdel-Ghany et al. (2005b) } \\
\text { Bernal et al. (2007b) } \\
\text { Sichul et al. (2007) } \\
\text { Sichul et al. (2007) }\end{array}$ \\
\hline ATX & $\begin{array}{l}\text { AtCCH } \\
\text { AtATX1 } \\
\text { LeCCH }\end{array}$ & $\begin{array}{l}\text { ATX1-like Cu chaperone } \\
\text { ATX1-like Cu chaperone } \\
\text { ATX1-like Cu chaperone }\end{array}$ & $\begin{array}{l}\text { Cytosol } \\
\text { Cytosol } \\
\text { Cytosol }\end{array}$ & Stem, vascular tissue & $\begin{array}{l}\text { Himelblau et al. (1998); Andrés-Colás et al. (2006) } \\
\text { Puig et al. (2007) } \\
\text { Company and González-Bosch (2003) }\end{array}$ \\
\hline $\operatorname{ccs}$ & $\begin{array}{l}\text { AtCCS } \\
\text { LeCCS } \\
\text { StCCS } \\
\text { ZmCCS }\end{array}$ & $\begin{array}{l}\text { Chaperone for Cu/ZnSOD } \\
\text { Chaperone for Cu/ZnSOD } \\
\text { Chaperone for Cu/ZnSOD } \\
\text { Chaperone for Cu/ZnSOD }\end{array}$ & Cytosol and chloroplast & Stem, flower, leaf & $\begin{array}{l}\text { Abdel-Ghany et al. (2005b); Chu et al. (2005) } \\
\text { Zhu et al. (2000) } \\
\text { Trindade et al. (2003) } \\
\text { Ruzsa and Scandalios (2003) }\end{array}$ \\
\hline
\end{tabular}




\begin{tabular}{|c|c|c|c|c|c|}
\hline & GmCCS & Chaperone for Cu/ZnSOD & Chloroplast & Mesophyll cells, leaf & $\begin{array}{l}\text { Sagasti S, Bernal, M, Picorel R, Yruela I, unpublished } \\
\text { results }\end{array}$ \\
\hline $\operatorname{cox}$ & $\begin{array}{l}\operatorname{AtCO} 17-1 \\
\operatorname{AtCOX17-2}\end{array}$ & $\begin{array}{l}\text { cox17-like Cu chaperone } \\
\text { cox17-like Cu chaperone }\end{array}$ & & & $\begin{array}{l}\text { Baladin and Castresana (2002); Wintz and Vulpe (2002) } \\
\text { Baladin and Castresana (2002); Wintz and Vulpe (2002) }\end{array}$ \\
\hline YSL & $\begin{array}{l}\text { ZmYS1 } \\
\text { AtYSL1 } \\
\text { AtYSL2 } \\
\text { OsYSL2 } \\
\text { AtYSL3 } \\
\text { TCYSL3 }\end{array}$ & $\begin{array}{l}\mathrm{Cu}^{2+}-\mathrm{NA} \text { complex transporter? } \\
\mathrm{Cu}^{2+} \mathrm{NA} \text { complex transporter } \\
\mathrm{Cu}^{2+}-\mathrm{NA} \text { complex transporter? } \\
\mathrm{Cu}^{2+} \mathrm{NA} \text { complex transporter? } \\
\mathrm{Cu}^{2+}-\mathrm{NA} \text { complex transporter } \\
\mathrm{Cu}^{2+}-\mathrm{NA} \text { complex transporter? }\end{array}$ & $\begin{array}{l}\text { Plasma membrane? } \\
\text { Plasma membrane } \\
\text { Plasma membrane? } \\
\text { Plasma membrane } \\
\text { Plasma membrane? } \\
\text { Plasma membrane }\end{array}$ & $\begin{array}{l}\text { Root, shoot } \\
\text { Pollen, vascular tissue, } \\
\text { peduncle, leaf } \\
\text { Root (endoderm pherycicle), } \\
\text { shoot } \\
\text { Leaf (phloem), seed } \\
\text { Pollen, flowers, root, leaf } \\
\text { Root }\end{array}$ & $\begin{array}{l}\text { Roberts et al. (2004); Schaaf et al. (2004) } \\
\text { Waters et al. (2006); Curie et al. (2009) } \\
\text { DiDonato et al. (2004); Schaaf et al. (2005) } \\
\text { Koike et al. (2004) } \\
\text { Waters et al. (2006); Curie et al. (2009) } \\
\text { Gendre et al. (2007); Curie et al. (2009) }\end{array}$ \\
\hline
\end{tabular}




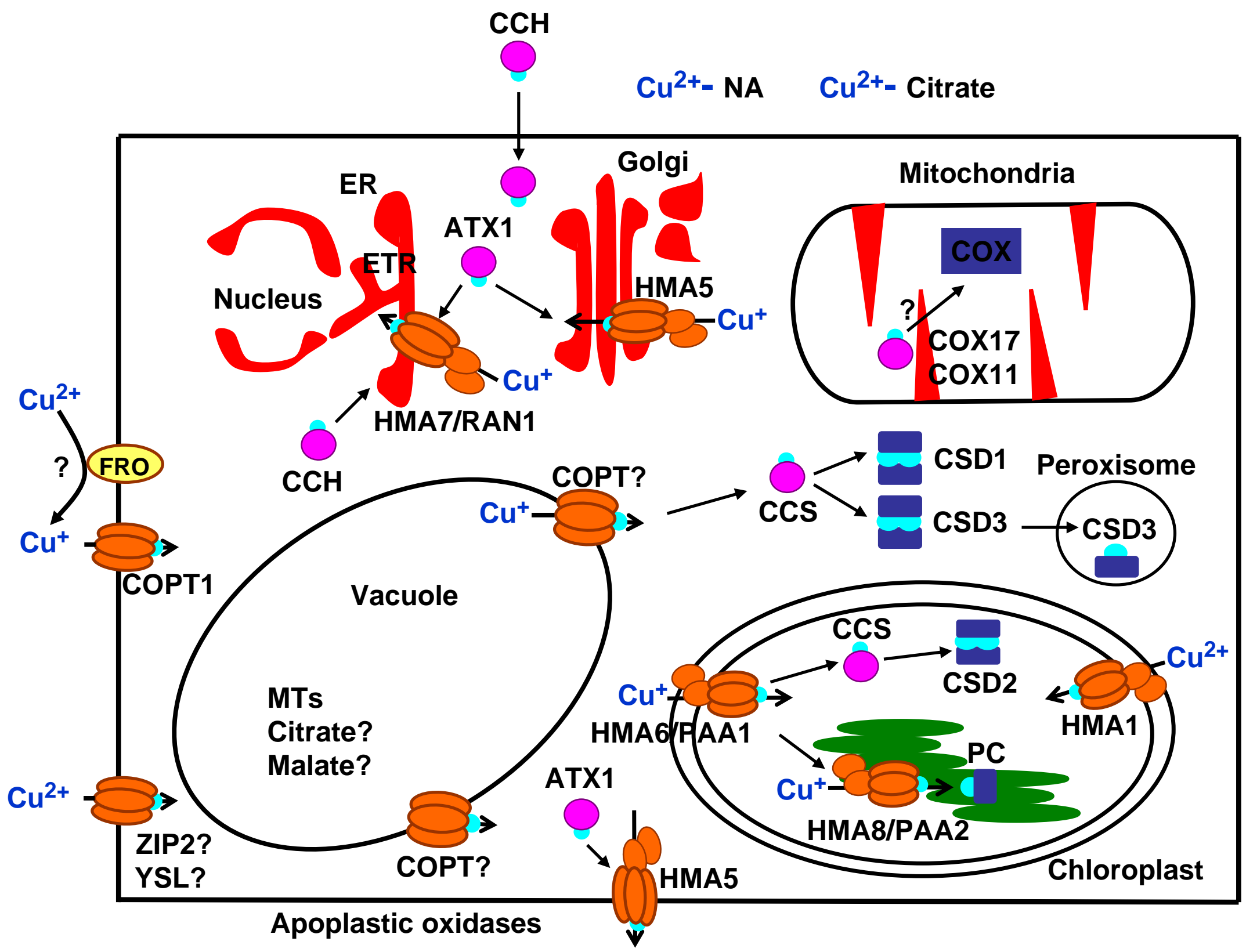

Figure 1 


\section{COPT}

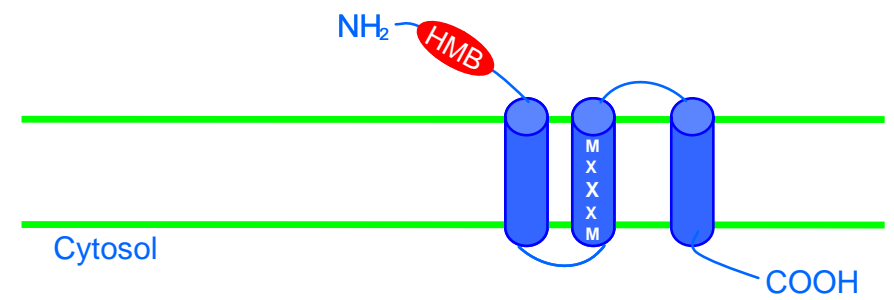

HMA6/PAA1

HMA8/PAA2
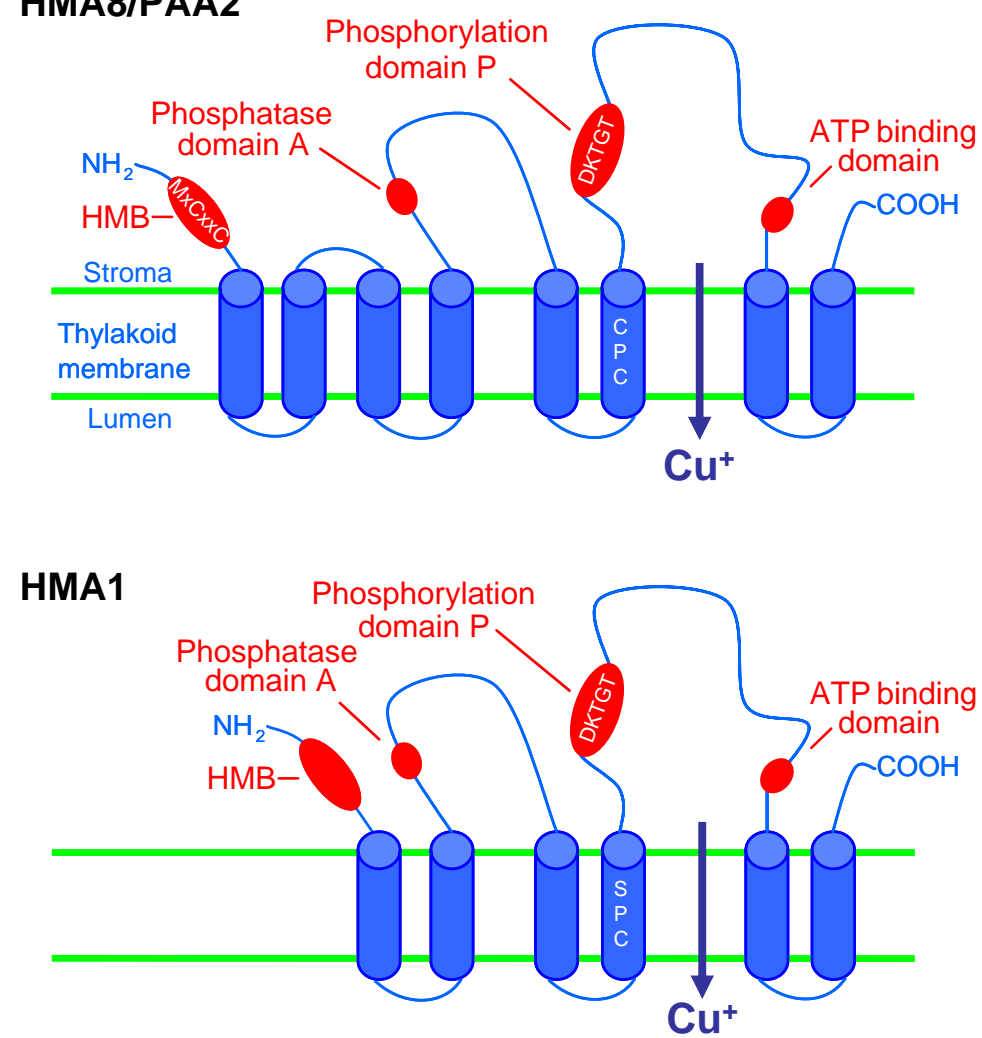

\section{HMA7IRNA1}

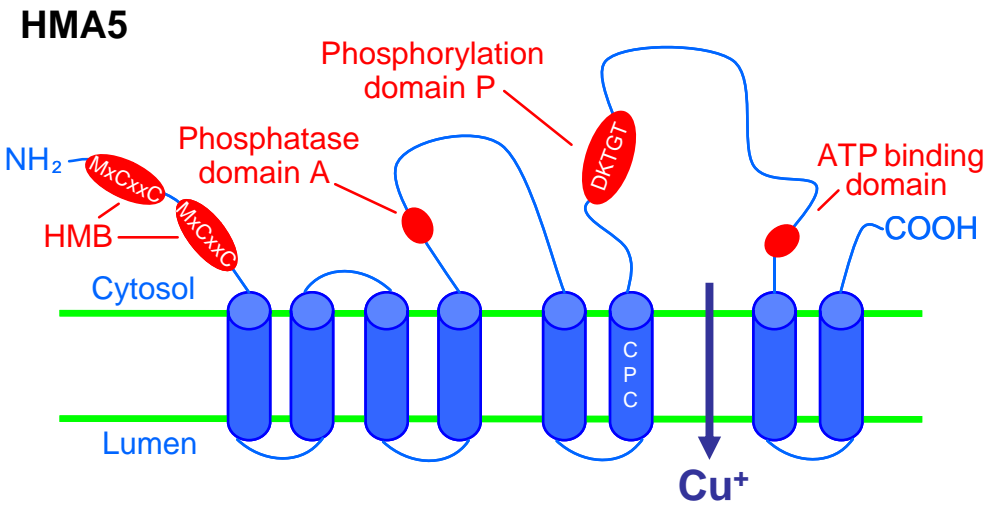

Figure 2 